K-GK UC-NRLF

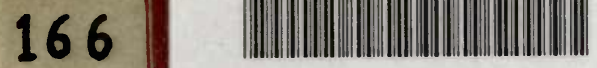

W5 B 3419798 


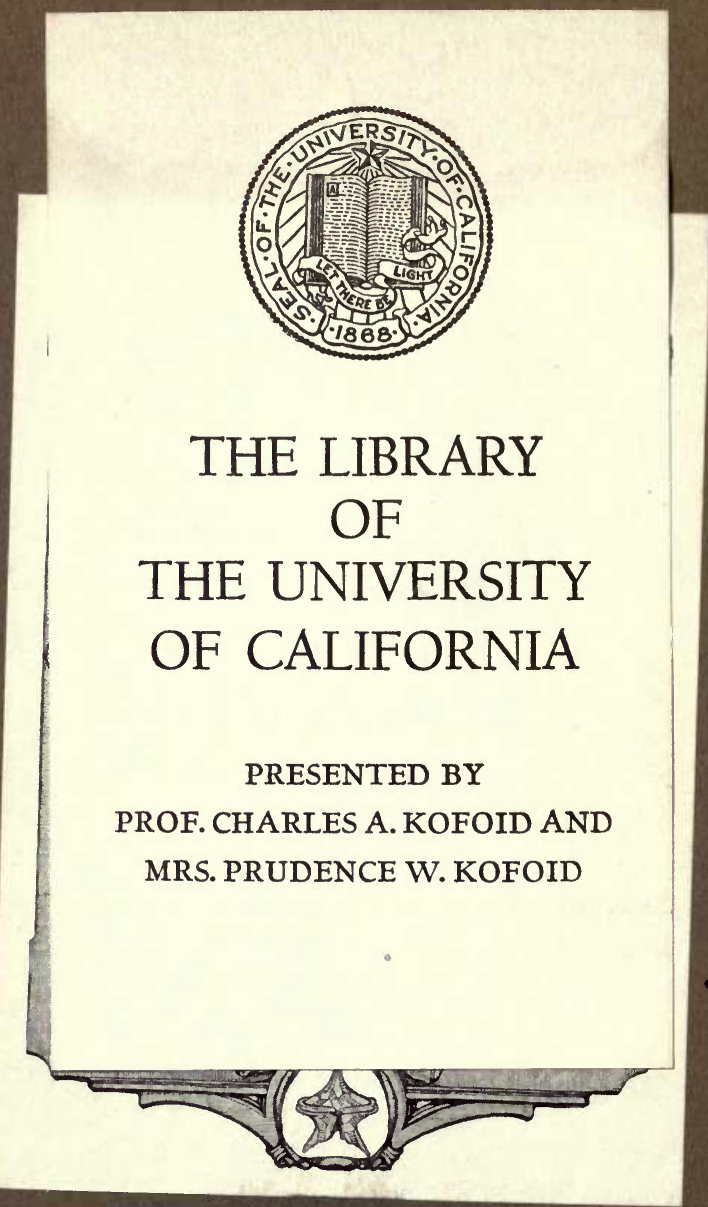




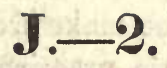

REPORT

\title{
ON THE INDIGENOUS MEDICAL BOTANY OF MASSACHUSETTS.
}

\author{
By Stephen W. Williams, M. D.
}

PRELIMINARY REMARKS.

TuE plants of Massachusetts have been pretty thoroughly investigated by able botanists. Although the State embraces but a small extent of territory, and much of the soil is rocky and barren, and although she is situated in a pretty high northern latitude, for the temperate zone, she, nevertheless, has some as warm weather as is to be found in the sunny regions of the south, though not of so long continuance. Many, if not most, of our plants are the same with those of the climate of the south and southwest. There are but few of the plants which have been described by botanical writers, as growing in the southern and southwestern States, which are not found in Massachusetts. Some of our western and southwestern States, however, are still in their infancy, and the natural history of them has not been much investigated. The admirable resolution of the Association for appointing a committee to investigate the medical botany of the various parts of the United States, will do much towards drawing out and developing the comparatively unexplored resources of our country in this department of science. Although considerable has been done in this respect, a great deal yet remains to be done, and the time will probably ultimately arrive, when many of what are now termed "worthless weeds, and useless plants," will be considered invaluable medicinal agents; and many which are now considered medicinal, will be considered comparatively of little value. The chaff will be sifted from the wheat, and a proper value will be 
attached to the most important medicinal plants. The subject, as yet, is almost in embryo, and much light will be thrown upon it by the investigations of our future medical botanists.

It is to the researches of regular scientific physicians, that much is to be expected in this department of our profession. The selfstyled botanic physicians, who make pretensions to the exclusive use of vegetables, in their empiric practice, employ but few articles in comparison with educated physicians, and with the exception of their divine lobelia, one of the most poisonous substances known in the vegetable or mineral kingdoms, their remedies are generally very inert. Nearly all the knowledge which they ever obtained of them, has been from the writings of regular physicians, and from our standard works upon Medical Botany and Materia Medica. We have no hopes that our vegetable materia medica will receive any valuable accessions from them. I have seen but in a very few of their writings, even a scientific botanical description of any of their boasted remedies, or even a reference to the natural orders of Jussieu or Lindley, or of the sexual system of Linnæus. The English or vulgar name generally is only given, which may mean one thing, or may mean another, but generally ends only in jargon and confusion, for the same English name often applies to a dozen different plants.

The only extensive early writer upon the medicinal plants of Massachusetts, which I recollect to have seen, was Dr. Cutler, who published an elaborate article upon the subject, in the Transactions of the American Academy of Arts, Boston, not far from the year 1790. The work is not now before me, and I may not be exactly correct in relation to the date. Separate monographs, or papers, have been published in the medical journals upon individual medicinal plants, but no regular system of botany was published in this section of the country, as far as I can ascertain, till some time after the commencement of the present century, when Waterhouse published his Botanist. Eaton published his Botany of the Northern States, not far from the year 1812 or 1814. He described almost all the plants then known in the northern part of our Union, according to the Linnæan scheme, with a reference to their natural orders. $\mathrm{He}$ speaks of the medicinal properties of all the plants which he describes, by referring them to the classes of Linnæus, and to his observation "that plants in the same class and order possess the same medicinal properties." If this observation is correct, then all plants are medicinal, and the poisonous hemlock possesses similar proper- 
ties with the aromatic caraway and anise. The work of Eaton has passed through several editions. Our indefatigable and learned Bigelow, about the same time, published his valuable and most interesting work upon the Plants of Boston. This learned work has passed through several editions. His more splendid work upon Medical Botany, was commenced not far from the year 1815, containing elegant coloured engravings of several of our most valuable medical plants. This, next to Wilson's Ornithology, was considered the most splendid work upon natural history which had been published in America. Barton, of Philadelphia, about the same time commenced a Medical Flora upon much the same plan, with superb engravings, in quarto. This, with that of Bigelow, was discontinued for the want of patronage, after the publication of three volumes. Muhlenberg, Pursh, Bartram, and the elder Barton, had published interesting works upon the subject of botany, and also Elliott, of South Carolina.

I had examined these works with great attention, and also several foreign works, and among the rest, Sowerby and Curtis. I became enamoured with the study of botany, and about the year 1816, in connection with Edward Hitchcock, now President of Amherst College, and Dr. Dennis Cooley, now of Michigan, who was then a student in the office of my father and myself. With them I examined the valleys and the mountains of my native town of Deerfield, for the purpose of discovering and investigating their vegetable and mineral productions. Our meadows, containing about two thousand acres, receive the deposit and wash of the Green Mountains in Vermont, as in a basin, as the Deerfield River in its meanderings, washes the base of those mountains for forty or fifty miles, and wafts on its tumultuous waves the seeds of various plants from those mountains, and deposits them in this fertile basin. Hence this little alluvial tract is peculiarly rich in botanical productions. Nearly one thousand species were found within the borders of this town in a single season, including those which were naturalized. Extensive herbariums were formed from these, and those of Dr. Cooley and Dr. Hitchcock were among the earliest and most valuable in the country. Both these gentlemen, I believe, still continue to add to their extensive collections. Dr. Hitcheock was much assisted in his early investigations upon this subject, by Miss Orra White, of Amherst, now his wife, one of our most distinguished naturalists, who, with her own hand, painted many of the plants collected with almost inimitable beauty. She still cultivates alm all the branches of 
natural history with great assiduity, as do the gentlemen mentioned above. President Hitcheock has long been considered the most learned geologist in America.

My object in attending to the study of botany, was to investigate the medical properties of such plants as we might discover in our peregrinations and wanderings. The field had been but partially explored, and many of our plants, in the language of the immortal Rush, were "exhaling their virtues in the desert air." After my marriage, in 1818, to Miss Harriet T. Goodhue, I was greatly assisted by my wife, who drew and painted most of the plants painted by Mrs. Hitchcock, besides very many others from nature, and from other sources. In subsequent years, this collection of paintings has been very much enlarged by my daughter Helen Maria (now Mrs. Huntington), and my younger daughter, Caroline Willard. The paintings now in my possession, principally of medical plants, from these and other sources, amount to several hundred, which, to me at least, are invaluable, and they have been of great service to me in my lectures on medical botany at Dartmouth Medical College, and upon materia medica in the Willoughby University of Ohio. This, in my opinion, is the most permanent and beautiful method of preparing what may be called a fac-simile of an herbarium. There is no danger of the destruction of the paintings from insects, and of the fading of the plants from the ravages of time. I have availed myself, also, of all the limited means in my power, to procure our valuable, and even costly works upon Medical Botany. In this way, I have enriched my library with the splendid work of W. P. C. Barton, with the beautiful plates of Michaux, and many other splendid works. While making my collection of coloured engravings of plants, I have devoted much of my attention to the investigation of the medicinal properties of the plants which have been found in this section of the country; and so long ago as the year 1819, I compiled a volume upon the medical virtues of our plants, culling information from every source within my reach, both regular and empirical, and I have been adding to that collection ever since. If I have not recorded much that is new, I trust I have at least enlarged the boundaries of our vegetable Materia Medica. In this report, however, of the Medical Botany of Massachusetts, I can only give an outline or skeleton of the properties of the plants enumerated. An extended account of their uses would comprise a volume of no inferior dimensions.

Rather than cumber the individual articles upon which I have 
treated in this report of the indigenous medicinal plants of Massachusetts, with the names of my authorities under the head of the articles treated of, I have preferred to group the principal part of them together in these remarks, without regard to names, to time and dates. I may here observe, that I have very briefly noticed more than three hundred medicinal indigenous plants found growing in Massachusetts, which is as far as I'have been able, at present, to investigate them. My list is, undoubtedly, very imperfect. Many more may be known which have escaped my notice. The list of valuable articles is increasing, and many years will not elapse before a perfect account will be obtained of them. Many of them, of which I have spoken, will, probably, be considered inert; and others will be deemed more valuable than they have been described to be. I have not treated of any article without some authority. Probably as many naturalized medicinal plants are to be found in Massachusetts, as indigenous. If so, our vegetable materia medica is rich, and will well repay further and deeper investigation. Had the Committee been called upon by the Association to investigate our exotic, as well as indigenous plants, my list of references to authorities would have been altogether greater. As it is, I shall mention only a few of those from whom I have received most important information. I have availed myself, among other works, of the knowledge communicated upon the subject, by Rees's Cyclopedia, Encyclopedia Britanuica, the new Edinburgh Encyclopedia, Willich's, the Encyclopedia Americana, Nicholson's, and the Cyclopedia of Practical Medicine, as far as published; of Michaux, Bartram, Weld, Flint, Drake, Peck, Darby, Schoolcraft, Morse, Godman, Wilson, Audubon, Carver, Pursh, Muhlenberg, Elliott, and many other writers upon our Southern and Western States, and travellers in those regions; of Catesby, Clayton, Kalm, Robbins, Charlevoix, and other celebrated travellers in America; all of whom have spoken, more or less, of our plants. To Silliman's Journal, the American Philosophical Transactions, the Transactions of the Academy of Arts and Sciences, of the Phil. Academy of Natural Sciences, the Journal of Pharmacy, B. S. Barton's Medical and Physical Journal, Barton's Elements of Vegetable Materia Medica, his Medical Botany, his Flora, \&c., both with splendid coloured plates, Coxe's Medical Museum, Coxe's Dispensatory, the Philadelphia Medical Recorder, the American Journal of the Medical Sciences, the Philadelphia Medical Examiner, Carson's (splendid) Medical Botany, with elegant coloured engravings, Griffith's Medical Botany, Rafi- 
nesque's Medical Flora (I have quoted largely from this latter work, though many of the virtues of the plants described by him depend rather too much upon the Indians to be considered absolutely established; he was, however, ranked among our most distinguished naturalists), the New York Medical Repository, the New York Medical and Physical Journal, the New York Medical Magazine, the New York Medical and Surgical Journal (and particularly to a most able article in it, upon the Medical Botany of the State of New York, by Dr. Charles A. Lee, the editor), the Lyceum of $\mathrm{Na}$ tural History of New York, and the writings of Mitchell, Torrey, Gray, Emmons, Dewey, Eaton, \&c.; the New England Journal of Medicine and Surgery, the Boston Medical and Surgical Journal, the works of Bigelow, Peck, and the indefatigable and learned Martyn Paine, Nuttall, and others, Sumner, Ives, Comstock, Tully, \&c. Each of the above journals and authorities, and many others to which time will not allow me to allude, contain numerous papers of much value, upon the medical properties of individual plants. Mrs. Lincoln's Botany, and the able and elaborate reports upon the subjects of natural history, to the Legislatures of the States of New York and Massachusetts. To the Professors Dewey and Hitchcock I am indebted, in a great measure, for my catalogue of the names of the indigenous medical plants of this State; and also to Bigelow, in his last edition of the Plants of Boston. To these latter works, to Gray and Torrey, to Lindley, Eaton, and many other standard writers on botany, some one or more of which must be in the possession of all my readers, I refer for particular descriptions of the plants which I have noticed. As a minute account of them would enlarge this report to the size of a volume, I merely refer the plants of which I speak to the natural orders and the sexual system.

Of Pharmacopoias, Dispensatories, Materia Medicas, and works upon Natural History, I have examined the ancient "Secretes of Alexis," in black letter, published in 1559; Culpepper's Herbal, published in 1653, containing coloured plates of more than four hundred plants ; Salmon's Dispensatory, 8th edition, 1716 ; Brooks' Natural History, and his Practice of Physic; Quincy's Dispensatory; the Edinburgh and London Dispensatories; the Eclectic Dispensatory; Pereira and Thomson's Materia Medicas and Dispensatories; Wood and Bache's Dispensatory; the Pharmacopoeia of the United States, and Sequel of the Massachusetts Medical Society; New York Hospital, \&c.; Paris's Pharmacologie; Dunglison's New Remedies; Smith's Physiology of Plants; the invaluable work of Lindley 
on Medical Botany, from which I have quoted largely; Evelyn's Sylva, folio; the able treatise on the Botanical History and Medical uses of British Plants, published in the early volumes of the London Medical and Physical Journal, and also to other articles in that work; Thomson's Abridgment, in quarto, of the Transactions of the Royal Society of London; Linnæus's Species Plantarum, 4 vols. octavo; De Candolle, Loudon, Willdenow, Sprengell, Woodville, Pennant, Lightfoot, Cullen, Rutherford, Ray, Murray, Hill, Duncan, Lindelstolphe, Dioscorides, Boerhaave, Duncan, Strack, Haller, Curtis, Gmelin, Wepfer, Hoffmann, Stokes, Bergius, Stork, and many other standard and scientific medical writers, which time will not permit me to enumerate. On this subject, I have also endeavoured to procure information from sources of even doubtful authority. From what may be considered by some as empirical authority. I have consulted the works of Henry, who has written a large volume upon Medical Botany, with numerous plates. Thomson's Manual, Mattson's Practice, with coloured plates, Stewart's Healing Art, and a host of herbals and family practices, which have been hawked about the country by pedlers and petty mapmen. I, too, have listened to the marvellous stories of illiterate old women and Indian doctors, concerning the virtues of plants, and have endeavoured to draw useful information concerning the medical virtues of our indigenous plants. From these results, some facts may be collected which will enable us to prepare an extended and useful vegetable Materia Medica of the United States.

Catalogue of the Indigenous Medicinal Plants growing in Massachusetts, as far as I can ascertain them; arranged according to the Natural System of Lindley, and to the Sexual Systems of Linnæus.

It is presumed that every physician possesses some elementary treatise on botany, which will describe the botanical history of the plant of which I treat. I shall not, therefore, give the botanical description of them, any farther than to refer to the orders, classes, \&c., as this would enlarge my paper to the size of a volume. 


\section{Class I. VASCULARES.-FLOWERING PLANTS.}

\section{Sub-Class I. EXOGENA; OR, DICOTYLEDONS.}

Tribe 1. Angiospermæ; or, seed inclosed in a covering, or pericarp. 2. Polypetalous and Achlamydeous Plants.

\section{Order 1.-Araliaceet; or, Aralita Tribe.}

1. Aralia racemosa. Spikenard. Class 5, Order 1, Linnæus. Eleven species of aralia are noticed in the new Edinburgh Encyclopedia.

2. Aralia nudicaulis. Wild sarsaparilla; wild liquorice; sweet root.

3. Aralia hispida, or Spinosa. Prickly ash; spikenard tree; angelica tree; prickly elder; toothache tree. These three aralias are officinal in the United States Pharmacopoeia, Wood and Bache, \&c. They are stimulant, emetic, cathartic. For an account of the specific medical properties and uses of the officinal plants of this State, I refer to the sequel of the U. S. Pharmacopoeia, Wood and Bache, and to the standard writers upon medical botany in the United States. I shall merely glance at the leading medical properties of such, without entering much into detail.

4. Panax quinquefolium. Ginseng; 5, 2, Linn.

This plant is stimulant, cordial, aromatic, tonic, and expectorant. It is considered the divine remedy among the Chinese, as much as the lobelia, or Devil's pepper, is thought to be such among the Thompsonians and steamers. In China, this plant is called ginseng, which, in the Chinese language, signifies man's health.

Order 2.-Umbelitferes, or Umbelliferous Tribe.

5. Conium maculatum; 5, 2, L. Water parsley; poison parsley.

6. Cicuta maculata. Water parsley; death of man; wild hemlock. 


\section{1}

7. Cicuta bulbifera. Water hemlock; 5, 2, L. These three plants are officinal. They are narcotic, anodyne; and, taken in over doses, they are virulent, narcotic, acrid poisons. Here is an instance, as I have stated in my preamble, which falsifies the assertion that plants of the same class and order possess similar medicinal properties. The anise, dill, and many other umbelliferous plants are aromatic and stimulant, and not narcotic and poisonous, while the coniums, cicuta, \&c., in large doses, are deadly poisons; and numerous instances have occurred of death having ensued from mistaking the seeds of cicuta for caraway, and the roots for parsley. Five species of conium have been discovered, and three of cicuta.

8. Daucus carota. Wild carrot; 5,2, I. Sixteen species known. Off. Stimulant, diuretic, carminative, and antiseptic. In the form of poultice as an antiseptic, few articles in the Materia Medica surpass it. It is found wild in Massachusetts, and it is also extensively cultivated as an esculent vegetable.

\section{Ligusticum. Eighteen species known; 5, 1, L.}

Ligusticum Scoticum. Smellage; lovage. It is sweet, aromatic, warm, and pungent, similar in its properties to opoponax angelica, \&c. Although the whole of the plant is used, the seeds are the most powerful. It is carminative, diaphoretic, and emmenagogue.

\section{Angelica. Five species known; 5, 2, L.}

Angelica triquinata. Wild angelica; sometimes, though erroneously, called cow parsnep. This plant is sometimes mistaken for cicuta, or poison hemlock, though their properties are entirely different. It is aromatic, tonic, carminative, and stomachic, and useful in colic, dyspepsia, \&c.

\section{Sanicula. Four species known; 5, 2, L.}

Sanicula Marylandica. Sanicle. It is supposed to be astringent, partially tonic, and diuretic, and it has been used with success in dropsy; and in decoction in dysentery, leucorrhoea, and hemorrhages. It is also pulmonary and balsamic.

12. Sium. Nine species known; 5, 2, L.

Sium latifolium. Water parsnep. Narcotic, supposed by some 
to be diuretic, emmenagogue, \&c. Rafinesque says the Sium latifolium is certainly poisonous.

\section{Smyrnium. Nine species known; 5, 2, L.}

Smyrnium aureum. Meadow parsnep; by many called cow parsnep; Alexanders. A warm debate has been carried on in the Boston Medical Journal, between Dr. Oliver Partridge and Dr. James Thacher, both over eighty years of age, whether this is the genuine cow parsnep, or whether the Heracleum lanatum, or masterwort, is not the cow parsnep. The former maintaining that the Smyrnium is the true cow parsnep, and the latter that the Heracleum is the genuine cow parsnep. We are too apt to be led astray by English names. Dr. Partridge is still living at Stockbridge, Mass., in the ninety-sixth year of his age. Dr. Thacher died at Plymouth, two or three years ago, over eighty years of age. After reading the debate, I leave it to my brethren to decide which is correct. Dr. Partridge has used the Smyrnium successfully in cases of epilepsy, while the late Dr. Orne, of Salem, has also used the Heracleum with success in this terrific disease. The Smyrnium is a warm, stimulating aromatic.

\section{Apium. Two species known; 5, 2, L.}

Apium graveolens. Celery, and wild celery. This plant grows wild in Massachusetts. It is stimulant, diuretic, and diaphoretic. It is used much, and successfully, in cases of strangury, gravel, \&c.

\section{Order 3.-Randnculaces, or Crow-Foot Tribe.}

\section{Hydrastis. One species known; 13, 13, L.}

Hydrastis Canadensis. Yellow puccoon; golden seal; yellow eye-bright; yellow root; Indian paint; ground raspberry. This is a very celebrated remedy with empiries, and, I believe, with the Thompsonians and steamers. The root is the part employed, which is very bitter, pungent, and nauseous. It is put down in the Secondary List of articles in Wood and Bache, and, I believe, in the U.S. Pharm. Rafinesque speaks of it as a tonic, detergent, and ophthalmic. It is in high reputation in Kentucky and Ohio for affections of the eyes. The Indians use it for ulcerated legs, and other local complaints. It is employed as a tonic internally, in infusion or tincture, in affections of the liver and stomach. This plant appears to be slightly narcotic. It is used in aphthous ulcerations. It deserves scientific investigation. 
16. Actæa. Three species known; $13,1, \mathrm{~L}$. These three are found here, and are

Actæa rubra; 17 . Actæa alba; 18 . A. racemosa. Cohosh; baneberry. They are all officinal. The roots are rather bitter, and are sometimes used as a tonic. They are also nervine. The whole plant and berries are said to be poisonous. They are used in decoction in chronic rheumatism, in the declining stage of fevers, in hysteria, \&c. They frequently induce perspiration. The recent plant appears to be stronger than the dry. It should be avoided in active inflammations. The actæa racemosa has sometimes been confounded with the cimicifuga racemosa.

\section{Aquilegia. Six species known; 13, 5, L.}

Aquilegia Canadensis. Columbine. This is sometimes cultivated in our gardens, though indigenous. It is similar in its properties to the A. vulgaris, which is said to be a gentle laxative, diuretic, and emmenagogué. Most parts of the plant are in use in Europe (Raf.). The seeds are acid, and somewhat oleaginous: and, infused in wine, they have been used in jaundice.

\section{Clematis. Thirty species known; 13, 13, L.}

Clematis Virginica. Virgin's bower. The fibrous part of this plant may be converted into paper. It is very acrid, and is employed as a caustic for the purpose of cleansing ulcers. The extract is used for pains in the bones, in doses of from one to two grains. Frictions of the oily liniment of it are said to cure the itch. It is also used as a diuretic and sudorific in chronic rheumatism, and in palsy. The bruised green leaves are employed by quacks as cathartics in foul ulcers. On account of the irritating properties of this plant, it was called by Stark and the older writers Flammula jovis. As a diuretic, he gave four ounces three times a-day, made by infusing two or three drachms of the leaves in a pint of water. A strong infusion, frequently applied, is said to cure the itch.

\section{Anemone. Thirty-three species known; 13, 13, L.}

Anemone nemorosa. Wood anemone; wind flower. Off. The whole plant, and, in fact, the whole of this genus, are very acrid and irritating. It is used as a substitute for Spanish flies. Kalm says the hairy leaves, infused in alcohol, are efficacious in toothache, when applied to hollow teeth.

voL. II. -56 
22. Anemone pratensis. The extract of this is said to be useful in cutaneous affections. Dose, two or three grains, gradually increasing to a scruple. On this point, Storck, Gmelin, and Bonnet all agree. The anemones are used in monthly suppressions. Hand's Phys. and Surgeon.

23. Coptis trifolia; $13,13, \mathrm{~L}$. Gold thread; mouth root. Off. Tonic, astringent, and in great repute in canker, and ulcerations of the mouth.

24. Hepatica triloba. Liverwort; 13, 13, L. This plant is brought into considerable repute, of late, for the cure of coughs and consumptions. Notwithstanding all the boasted panaceas of the quacks, this fell destroyer still reigns triumphant, and probably the day will never arrive when seated consumption will be curable.

25. Thalictrum. Twenty-seven species known; 13, 13, L.

Thalictrum dioicum. Meadow rue. A poultice made of the leaves of this plant has been known to relieve the pain of sciatica. The roots of some of the species have been considered useful in the bites of snakes, and the leaves have been used in making spruce beer.

26. Caltha palustris; 13, 13, L. Cowslip; Marsh marygold. An excellent pot herb, though acrid when young.

27. Ranunculus. Eighty-eight species known; 14, 1, L.

Ranunculus acris. Buttercup; crowfoot; yellow weed; meadow bloom; yellow pilewort. This is put down in the secondary list in the United States Pharmacopœia. It is an acrid and poisonous plant. From depending on the English name, some have mistaken the geranium maculatum for this. See a communication from Dr. Partridge and myself, in the Boston Medical and Surgical Journal, vol. xviii. March 28, 1838. This plant is so acrid that it has hardly ever been given internally, as it is apt to occasion inflammation of the stomach. Applied to the skin, it will blister speedily, and does not produce strangury like the Spanish fly.

28. The Ranunculus sceleratus possesses properties similar to this. 
29. Delphinium. Sixteen species known; 13, 8, L.

Delphinium consolidum. Larkspur. Sec. U.S.P. This plant is supposed to possess the properties of delphinium staphisagria, which has been much employed in medicine. It has been thought to possess the power of healing or consolidating wounds; hence the name consolida. The seeds are acrid and diuretic, and produce vomiting and purging. A tincture, prepared by infusing an ounce of the seeds in a pint of alcohol, has been of service in spasmodic asthma, and in dropsy, in the dose of ten drops, gradually increasing until the system is affected. This tincture kills lice on the human head.

30. Aconitum. On the authority of Dewey, I place this among the indigenous plants of Massachusetts. Sixteen species known; 13, 2, L.

Aconitum napellus. Wolf's-bane. Off. Schœpf says this plant grows in Virginia. It is a most powerful narcotic, for the properties of which I refer to Wood and Bache, U. S. Pharm., Orfila, and other standard writers.

31. Nigella. Five species known; 13, 5, L.

Nigella damascena. Fennel flower. Sec. It is used in medicine merely as an aromatic.

\section{Cratægus. Nine species known; 12, 2, L.}

Cratægus coccinea. Thorn-bush. Fruit red or yellow, acid or sweetish. They are made into preserves, which are stomachic, antiemetic, and good against diarrhoa. The leaves and flowers are pectoral, and used in hooping and other coughs.

\section{Order 4.-Papaveracem.}

33. Chelidonium. Six species known; 13, 1, L.

Chelidonium majus. Celandine. Sec. This plant is acrid and pungent, diuretic, diaphoretic, and expectorant. Formerly much used for the cure of warts and herpetic eruptions. Much was said of it formerly as being famous for the cure of syphilis. But little dependence is now placed upon it in this affection.

34. Sanguinaria. One species known; 13, 1, L.

Sanguinaria Canadensis. Blood-root; puccoon, \&c. Off.

Most elaborate treatises have been written upon this most valuable plant by all writers upon botany and medical botany, and many 
medical writers. The most extensive article ever published on this subject was written by Dr. Tully, of New Haven, and published in the Philadelphia Medical Recorder, to which the reader is referred. To me it has always been a subject of wonder that the steamers, or Thompsonians, had not selected this article for their almost divine adoration, rather than their more dangerous lobelia.

\section{ORder 5.-Nymphiaces.}

35. Nymphr. Ten species; 13, 9, L.

Nymphre odorata. White pond lily; sweet pond lily. Sec.

In my practice, I have found a poultice of the root of this plant more efficacious as a suppurative application than any other article I have ever used. It is grated either in the dry or green state, and boiled in milk and water and thickened with bran to the consistence of a poultice. I have never used the plant for any other purpose, though it may possess the other properties spoken of by writers on the subject.

36. Nuphar advena; 13, 1, L. This was taken from the genus Nymphæ (yellow water lily). It possesses properties similar to the nymphæ, but in less degree.

\section{ORDER 8.-PODOPHYLLIA.}

37. Podophyllum. Three species and several varieties; $13,1, \mathrm{~L}$. Podophyllum montanum, vel peltatum. Mandrake; May apple, \&c. Off. This is one of our best cathartics. The fruit is edible.

\section{ORDER 9.-CRUCIFER}

38. Sinapis. Twenty-six species known; 15, 2, L.

Sinapis nigra. Black mustard. Off. The external employment of this article in the form of cataplasms is almost superseding the use of cantharides.

39. Raphanus raphanistrum; 15, 2, L. Charlock, or chadlock. This plant is similar to mustard in its properties. It is a pernicious weed to our farmers, choking up their oat-fields.

40. Lepidium. Thirty-seven species known ; 15, 2, L.

Lepidium Virginicum. Pepper cress; wild pepper grass. This . plant is aromatic, acrid, and diuretic. It is useful in scurvy, asthma, dropsy, \&c. Raf. 
41. Cochlearia. Twelve species known; 15, 2, L.

Cochlearia armoracia. Horseradish. Off. This is a warm stimulant rubefacient. In addition to the other properties of it mentioned by writers on the subject, an infusion of it in milk, and sweetened with honey, is a most efficacious gargle for hoarseness.

42. Cochlearia officinalis. 15,2, L. Scurvy grass. Off. Similar in its properties to horseradish; used in chronic obstructions of the viscera, in the scurvy, and in chronic rheumatism. A healthy, early salad. The infusion of the plant in wine, or the juice of it, is a good application in spongy gums. By distillation, alcohol is impregnated with its virtues, and the distilled spirit is useful in paralysis. (Wood and Bache.) The fresh root is purgative, and has been used after poisoning by corrosive sublimate.

43. Thlaspi bursæ pastoris. Shepherd's purse.

44. Dentaria diphylla. Tooth root.

45. Cardamine Pennsylvanica.

46. Draba verna. All the above possess properties similar to the cochlearias.

Order 10.-Fumaraces.

Fumaria. Thirty species; 17, 18, L.

47. Fumaria officinalis. Fumitory. Sec. This plant is tonic, bitter, and antiscorbutic. It is in extensive use for cutaneous eruptions. Its virtues principally reside in the dried plant. It has been said to cure the epilepsy. A notorious empiric directs to pour two quarts of boiling water on two ounces of the dried plant, and he uses it in all foul eruptions of the skin, by letting the patient drink constantly of it, and washing the parts freely with it. For a stomachic, infuse two ounces of the dried leaves and plant in three pints of Madeira wine, rum, or brandy, of which the dose is a wineglassful of the wine, or a tablespoonful of the spirit three times a day, on an empty stomach.

Order 11.-Capparides.

48. Cleome. Twenty-four species known; 15, 2, L. 
Cleome dodecandria. False mustard. Used in Cochin China as a counter-irritant in the same way as mustard. The root is used in the United States as a vermifuge.

\section{ORder 12.-Berberidea.}

49. Berberis. Barberry; 6, 1, L.

Berberis vulgaris. Barberry. Sec. The whole plant is agreeably acid. It probably contains the tartaric acid. The bark is of a yellow colour, and bitter. The red berries and the leaves are refrigerant, and slightly antiscorbutic. The conserve is an agreeable acid, somewhat purgative. It has been used in leucorrhœa, canker in the mouth, \&c.

\section{Leontice. Four species; 6, 1, L.}

Leontice thalictroïdes. Cohosh; pappoose root; squaw root; yellow ginseng, \&c. This plant is different from the Actæas, which are sometimes called cohosh, and must not be confounded with them. It is the Caulophyllum thalictroïdes of Rafinesque. The root is the only part employed. It is demulcent, antispasmodic, sudorific, and emmenagogue. The Indians recommend it in colic, sore throat, rheumatism, dropsy, and a variety of other complaints. The Indian women use it successfully in cases of lingering parturition, by giving constantly a strong tea of it during labour, or a week or two before the expected period. It appears to be peculiarly suited to female complaints. It is a powerful emmenagogue, and promotes the delivery of the menstrual flux, and dropsical discharges. It should be given in warm infusion, decoction, tincture, syrup, or cordial. It contains gum, resin, and oil. Raf.

\section{Order 13.-Magnoliacea.}

51. Liriodendron tulipifera; $13,13, \mathrm{~L}$. White wood tulip tree. Sec. This stately tree, which bears the most magnificent flowers, is seen in Massachusetts. I have seen immense forests of it in all their grandeur in the Western States. The bark, particularly the bark of the root, is stimulant, tonic, and diuretic. It is much used in rheumatism, intermittents, dyspepsia, \&c. It has been proposed as a substitute for Peruvian bark; used for bots in horses, and worms in children. An elegant coloured plate of it may be found in those splendid works, Bigelow's Medical Botany and Barton's Flora. 
52. Magnolia. At least nine species to be found in the United States; 13, 13, L.

Magnolia glauca. Beaver tree, \&c. Sec. This species extends throughout the New England States. It is similar in its properties to the Liriodendron, but more bitter and tonic. Dr. Procter found, upon analysis, that the bark of the Magnolia glauca afforded a volatile oil, a green resin, and a peculiar crystallizable substance similar to Liriodendron.

\section{Order 14.-Laurinea.}

53. Laurus. Forty-one species; 9, 1, L.

Laurus benzoin. Fever-bush; spice-wood, \&c. Sec. Every part of the shrub has an agreeable, spicy taste; but it is strongest in the bark and berries. It makes an agreeable aromatic drink in infusion or decoction; and is useful, like sage, in fevers. By some, it is considered vermifuge. It has, also, been used extensively in intermittents. The dried and powdered berries were used, during the Revolutionary war, for allspice. The oil of the berries is stimulant, and is used for bruises, itch, colic, \&c. The leaves and berries are used in dysentery. Raf. Lindley.

54. Laurus sassafras. Off. The root of this plant is highly aromatic and stimulant. The pith is very demulcent, and forms a mucilage which is useful in dysentery, catarrh, and ophthalmia.

\section{Order 24.-MALVACEA.}

55. Althæa. Ten species known; 16, 13, L.

Althra officinalis. Mallows. Off. This plant, although ranked among those which are naturalized, is also indigenous in Massachusetts. It is very mucilaginous; and Buckholdt states that the dry roots of this plant, boiled in water, give out half their weight of a gummy matter, very similar in its properties to gum tragacanth, gum Arabic, \&c., and which will more speedily dissolve gum myrrh and other resins than gum Arabic, starch, \&c. It is one of our purest demulcents.

56. Hibiscus. Sixty-nine species; 16, 13, L.

Hibiscus palustris. Marsh hibiscus; sweet weed. This plant is also demulcent. The hibiscus esculentus is edible, and is considered a delicacy. 
57. Malva. Sixty-two species; 17, L.

Malva sylvestris. High mallows. Off.

58. Malva crispa. Curled mallows.

59. Malva rotundifolia. Round mallows. All the species of mallows are mucilaginous and emollient, and are useful in catarrhal affections, dysentery, and in all the affections of the urinary organs. Both the high and the low mallows are much used as emollient enemas. They are also used in emollient poultices for tumours and inflammations. They are of service in gonorrhoa, and in sorethroat and lungs.

60. Sida abutilon. Indian mallows. This plant is also emollient and diuretic.

\section{Order 25.-TILIACEex.}

61. Tilia Americana. Bass-wood, or Linn; 13, 13, L.

This is one of the most valuable trees we possess, not only on account of the lumber it produces, but on account of its medicinal properties. Withering says it makes the best charcoal for gunpowder, drawing, \&c. I have long wondered why it has not been adopted into our materia medica as an officinal. Dr. Walmsley first called the attention of the public to it as a remedy in burns, in a letter to Dr. Benjamin Smith Barton, of Philadelphia, as early at least as 1803, and it was published in his admirable Medical and Physical Journal. The part of the bark made use of by Dr. Walmsley is the liber or inner bark. He generally used it freshly taken from the tree; but it answers very well when carefully dried. In either case, it is cut into small pieces and macerated in cold water, frequently stirring it about: In a short time, the water becomes extremely viscid, and with this the injured part is kept constantly wetted. In addition to its mucilaginous properties, it is also slightly astringent. I agree with Dr. Walmsley, from whom I first derived my information on the subject, that I have found more benefit from it in cases of burns than from any other remedy which $I$ have ever employed. I more frequently make it into a poultice by boiling the inner bark in milk and water, to the consistence of a mucilage, and make a thin poultice by the addition of a little wheat or rye bran, and apply it to the affected part. It is much more soothing than any other application I have ever tried, giving relief when topical 
anodyne applications have failed. I now use it very extensively in old wounds, bruises, and ulcers. I do not recollect that any writers upon materia medica or medical botany, except Dr. Walmsley, have ever recommended this valuable article.

\section{ORDER 36.-HYPERICEANEA.}

62. Hypericum. One hundred species ; 13, 5, L.

Hypericum perforatum. St. Johnswort. Sec. The leaves are astringent; an infusion has been used in gargles and lotions (Lindley). This plant is balsamic, somewhat styptic, pectoral, vulnerary, and bitter. The flowers are the parts which are principally used. Although they are of a yellow colour, they have the property of dying oils red. Infused in bear's fat or olive oil, they make a beautiful, red, balsamic ointment for sores, wounds, tumours, ulcers, and rough skin. The infusion of the leaves is of service in affections of the breast and lungs. It is also used in diarrhœa, hysteria, mania, and low spirits. A syrup of it, with sage, is said to be efficacious in croup. Formed into an ointment with bark of elder, stramonium, and bittersweet, and used in scirrhosities in the breast, it is thought to be very efficacious. Raf. According to B. S. Barton, this plant infused in spirit is a valuable remedy in diarrhœa, and in obstructed perspiration. The Germans in Pennsylvania consider it a specific in cases of diarrhœa. The season in which the plant is to be gathered and dried is from the end of June to the first of August. It is called St. Johnswort on account of its being in blossom on St. John's day. Dr. Muhlenberg first recommended this plant in diarrhoeas and dysenteries. It is supposed that it is the balsam or essential oil which is to be found in the perforations of the leaves or petals, which impart a fine colour to the spirit in which they are infused. When it is given to children for what is called the "summer disorder," or vomiting and purging, Dr. Withering recommends this tincture, prepared with brandy, with the addition of a small quantity of cinnamon, given in a little sweetened water. It should not be given in dysentery till after purgation; but in diarrhoea we need not wait for this. It is a plant which deserves further investigation. See an interesting article on it in.Barton's Med. and Phys. Journ.

63. Hypericum Virginicum. Virginia St. Johnswort. This plant possesses properties similar to the above. 


\section{ORder 38.-SAXIFragez.}

64. Saxifraga. Seventy species; 10, 2, L.

Saxifraga Pennsylvanica. Rock saxifrage. This plant is bitter and astringent. The roots are useful in gravel. Raf.

65. Mitella diphylla. Currant leaf; 10, 2, L. This plant is refrigerant, and is much used as a cooling drink in fevers.

66. Tiarella cordifolia. Miterwort; 10,2, L. The root is considered to be both mucilaginous and pectoral.

\section{Order 39.-Hamameliacez.}

\section{Hamamelis ; 4, 2, L.}

Hamamelis Virginica. Witch-hazel; winter bloom; pistacha nut. Sec. This singular shrub does not begin to flower till late in the fall, and the flowers do not drop off till winter. The fruit does not ripen till the following fall. The bark is a bitter astringent, with a sweet and somewhat pungent taste. By the Indians it has been employed as a sedative and resolvent in painful tumours, and in external inflammations. It may be used in the form of a poultice, or of a wash in the piles, and in inflammation of the eyes. The infusion of the leaves is similar in its properties to that of the bark, and is given in affections of the bowels, and in hemorrhagic complaints. A tea made of the leaves is good in suppression of the menses, for pain in the side, breasts, \&c., and for hematemesis. It is thought to be a mild astringent, and may be used as a substitute for statice and many other mild astringents. Raf. It is thought by some to possess anodyne properties; but I am not aware of the fact.

\section{Order 49.-Circoraces.}

68. Circæa lutetiana, 2, 2, L. Enchanter's nightshade. It derived its name from being much celebrated in former times in the mysteries of witchcraft, and for the purpose of raising the devil. This superstition is fostered from the fact of its growing among the mouldering bones and decayed coffins in the ruinous vaults of Strafford church in Lincolnshire, Eng. Darwin, in his Botanic Garden, has some amusing remarks upon it in connection with animal magnetism. The enchanters made use of this method by the employment of this plant. This same kind of enchantment, without the use of this plant, was revived in this country in $\mathbf{1 8 3 7}$ and 1838, and the mummery went down the throats of many of 
our easily-gulled people. The good sense of the great body of our inhabitants is, however, fast consigning it to the "tomb of all the Capulets."

\section{ORdER 52.-SALICARLIA.}

69. Lythrum verticillatum. Willow herb. This plant is slightly astringent, and somewhat mucilaginous. It is of some use in diarrhœas and dysenteries.

\section{ORDER 62.-ARISTOLOCHIA.}

\section{Asarum. Four species; 12, 1, L.}

Asarum Canadense. Wild ginger; snakeroot. Sec. A warm, stimulant; aromatic, like the aristolochia serpentaria, but not emetic. Lind. It is also similar in its properties to the Virginia snakeroot, but more aromatic. Its properties may be extracted by water and by spirit. It is said to be injured by boiling. It is useful in the low stages of fevers, in nervous affections, palpitations, and similar complaints. When a company of Indians from Canada were in Deerfield, in the year 1837, I was affected with palpitation of the heart, and they were much offended with me because I would not take one of their preparations which contained a large proportion of this snakeroot. They use it extensively in many complaints. The best preparation is said, by Rafinesque, to be a cordial made with the tincture and syrup. The tincture is coloured dark red by the resin. A fine cephalic snuff may be made of the powder of the root, useful in disorders of the head and eyes. A pleasant kind of wine or beer may be made, by infusing the whole plant in fermented wine or beer. Dr. Firth says he cured tetanus with a decoction of the roots.

\section{ORDER 73.-ROSACEA.}

71. Rosa. Fifty-one species; 13, 13, L.

Rosa rubiginosæ. Sweet-briar.

72. Rosa canina. Dog-rose. These two species are indigenous. The properties of all the roses are similar. As some of them are officinal, I refer the reader to the standard works on the materia medica, and to our pharmacopoias.

73. Potentilla. Fifty-four species; $12,13, \mathrm{~L}$.

Potentilla reptans. Cinquefoil. 
74. Potentilla Canadensis. Five finger. The above are mild astringents, and have a bitterish, sweetish taste. They were formerly in some demand for the cure of diarrhœas, and in those cases where mild astringents were required. Properties similar to tormentilla.

75. Geum. Fifteen species; 12, 3, L.

Geum urbanum. Synonym-Geum rivale; Geum Virginianum. Off. Avens-root; chocolate-root; herb bennet; cure-all; throatroot. This plant is strongly astringent, tonic, and stomachic. It contains tannin, adaganthine, gum, resin, and a peculiar oil heavier than water. Raf.

76. Agrimonia. Five species; 12, 2, L.

Agrimonia eupatoria. Common agrimony. Sec. Celebrated as a vermifuge; also used in decoction as an astringent gargle and lotion. A common ingredient in "herb teas." Lindley. It has been used in diseases of the genital organs, according to Alibert, and Pallas says it has been employed in Russia, as a remedy for worms in domestic animals. The Cyclopedia of Practical Medicine says it is employed in the materia medica of the Indians, who use it as a febrifuge; and Kalm says the Canadians use it in the same manner, and for the same purposes. Its virtues reside in an essential oil, which turns black with the salts of iron.

77. Fragaria. Nine species; 12, 13, L.

Fragaria vesca. Common strawberries were used medicinally in the days of Hoffmann and Linnæus, and have been considered useful in consumption, gout, scurvy, and gravel. They are considered refrigerant, diaphoretic, pectoral, and astringent. Infused in water, they have the property of curing chilblains, when washed by it. The roots are tonic, astringent, and bitter. They contain tannin and gallic acid, and are good in diarrhœa, hemorrhages, \&c. A popular remedy in dysentery, according to the newspapers, is to chew the whole plant and swallow it.

78. Rubus. Forty-six species; 13, 13, L.

Rubus villosus. High blackberry. See Bigelow's splendid plates, and a description in his elegant Medical Botany. 
80. Rubus strigosus. Red raspberry.

81. Rubus odoratus. Flowering raspberry. The berries of these plants are well known and delicious. The roots are astringent and tonic.

82. Prunus; 12, 1, L. Plumbs and cherries. Rafinesque says there are forty wild species known, and only twenty-five described by authors. The most medicinal are the Prunus Virginiana, serotina, and Canadensis. The bark of all these is bitter and astringent, and contains prussic acid. These barks are the bases of several quack medicines for the cure of consumption. In large doses, the bark is narcotic and vermifuge.

83. Sorbus. Four species; 12, 2, L.

Sorbus Americana. Mountain-ash; service tree. Indian name, Moosee Missy. This elegant tree, whose clustered red berries adorn our door yards during the winter, is valuable as a medicine. The bark tastes and smells very much like cherry tree bark; but it is more astringent, and contains prussic acid. It is used like the Peruvian bark. The Indians recommend it as a tonic in diseases of the heart.

84. Spiræa. Twenty species; $12,5, \mathrm{~L}$.

Spiræa tomentosa. Hard-hack; steeple bush. I have found this to be one of our most powerful astringents, both in the form of infusion and extract. It is also powerfully tonic. It may be used after proper evacuations in diarrhoea, dysentery, and cholera infantum. It is also useful in cases of debility, in the absence of inflammation and fever. It agrees better with the stomach than any other astringent. Dose of the extract from five to fifteen grains; of a very strong decoction, from one to two ounces. It is well worthy of a place as an officinal in our Materia Medica.

85. Spiræa alba. White hard-hack. Is similar in its properties to the above.

\section{Order 77.-Leguminose.}

86. Apios. 17, 10, L.

Apios tuberosa. Ground-nut; Indian potato. The root is esculent, and was formerly cultivated by the Indians. It deserves 
further cultivation, especially since we are suffering from the potato rot, as it is quite as nourishing, it is supposed, as the potato.

87. Cassia. Seventy-five species; 10, 1, L.

Cassia Marylandica. American senna; wild senna. Off. All the species of senna are simply cathartic, though some operate more powerfully than others; and they are apt to occasion griping, unless qualified by the seeds of anise, caraway, \&c. 'The American senna is not so powerful as the East Indian, or Alexandrian; the latter is much the better. The dose of the American senna is one ounce in decoction. A tea of the leaves makes an excellent enema. Senna enters into many of our compounds; as, the senna electuary.

88. Lupinus perennis. Common lupine. The seeds are bitter and tonic.

89. Trifolium. Eighty-five species; 17, 10, L.

Trifolium arvense. Clover; field clover. The flower contains a good deal of honey. The blossoms of

90. Trifolium repens, white clover, were once used in gout. They are moderately astringent. The steamers make a salve of the heads of red clover, which they use in the cure of cancer.

91. Melilotus. Two species; 17, 10, L.

Melilotus officinalis. Melilot; melilot clover. Sec. This plant has a peculiar flavour resembling that of the Tonquin bean, and it has been used for the same purpose to scent snuff. It is pectoral and demulcent, and is employed for dysuria, coughs, and leucorrhoea. It is also used in emollient poultices. The melilot is a principal ingredient in Kitteridge's celebrated bone ointment.

\section{ORder 78.-URTICACEA.}

92. Urtica dioica. Stinging nettle; 20,4, I. This plant is antiscorbutic, diuretic, and astringent. It has been supposed to have some efficacy in consumptive complaints; but its power must be feeble in this respect. A writer in the Boston Mercantile Journal values it highly as one of the most valuable styptics known. It is a healthy pot herb. Its sting is one of the most irritating known. The following lines are not inapplicable to it. 
"Tender handed, touch the nettle,

And it stings you for your pains;

Grasp it like a man of mettle,

And it soft as silk remains.

Thus it is with common natures:

Treat them kindly, they rebel ;

But be rough as nutmeg graters,

And the rogues obey you well."

93. Urtica pumila, vel adesia. Water nettle; stingless nettle. The footstalks of the leaves and of the stem of the plant are filled with water so as to make them transparent. Bind the leaves upon scrofulous sores, and they allay the irritation. They are said to be excellent for wounds, and also for eruptions.

94. Humulus. Six species; 21, 5, L.

Humulus lupulus. Hop. Off. The properties of this wellknown narcotic and sedative are now as well known as opium or cicuta. My late friend, Dr. A. W. Ives, of New York, first directed the attention of the faculty to the farina of the plant, which he named lupuline.

\section{ORDER 88.-EUPHORBIACE}

95. Euphorbia. One-hundred and fifty-five species; 19, 3, L.

Euphorbia maculata. Spotted spurge; Bowman's root; emetic weed. The properties of the Euphorbias are generally diaphoretic, astringent, emetic, cathartic, rubefacient, blistering, and stimulant, according to the different species. By many, some of the species are considered equivalent to ipecacuanha. For cathartic operation they are considered equal to jalap or scammony, and it requires but half the quantity to purge that these famous medicines do. They deserve the further consideration of physicians.

96. Acalypha. Thirty-nine species; two in the United States; 20, 16, L.

Acalypha Virginica. Three-seeded mercury; mercury weed. This species is found in all the States in the Union. It has been found by $\mathrm{Dr}$. Atkins to possess diuretic and expectorant properties, and it has been used in various species of dropsy, and in asthma. The quacks at the South use it extensively for various purposes, according to Elliott, the southern botanist. 


\section{ORder 122.-Geraniacex.}

97. Geranium. Forty-two species; 16, 10, L.

Geranium maculatum. Crows-bill, sometimes, though improperly called crow-foot. Off. This is one of our purest astringents, accurately and beautifully drawn and described by Bigelow and others, to whom I refer the reader.

98. Geranium Robertianum. Herb Robert. This plant has much reputation with many people for the cure of bloody water in cattle and horses, and also for the cure of bloody flux in them, and it is thought by some more efficacious in these complaints than most of the common medicines in use. It is employed in tanning in Germany, like the other species of geranium. It is diuretic, and less astringent than the G. maculatum, and, therefore, more proper in nephritis, and diseases of the bladder. It has been used in fever and ague, and as a gargle for sore mouths and throats.

99. Oxalis acetosella. Wood sorrel; 10,5, L. Off. From this plant the oxalic acid is prepared, which is so extensively employed in medicine. This plant is a good diuretic. Boiled in milk, it yields an acid whey. It is useful in affections of the kidneys. The oxalic acid, taken to a considerable extent, is poisonous. The leaves should, therefore, be used with moderation. One hundred pounds of the leaves give thirty pounds of juice, which yield ten ounces of superoxalate of potash. This is sometimes used under the name of salts of lemon. A conserve and syrup are made of the leaves, which are pleasant medicinal preparations, but perhaps inferior to currant jelly, and other acid fruits. Raf.

100. Oxalis stricta. Possesses similar properties.

\section{ORDER 126.-BALSAMINA.}

101. Impatiens. Thirteen species; $5,1, \mathrm{~L}$.

Impatiens noli me tangere, vel pallida. Touch-me-not; jewel weed. Sec. The whole plant is acrid. When taken internally, it operates as an emetic, cathartic, and diuretic. Dr. Ruan, of Philadelphia, employed it successfully in piles, by boiling the plant in a recent state in lard. The impatiens balsamine of the gardens possesses the same properties as the noli me tangere. W. and B. 


\section{Order 129.-Polygalacez.}

102. Polygala. Ninety-four species; 17, 3, L.

Polygala sanguinea, vel P. paucifolia. Flowering winter-green. The properties of this plant are similar to Polygala senega. The taste and smell are similar to Gaultheria procumbens. It is stimulant and sudorific. It is milder than seneka, and may be useful in rheumatism, dropsy, and asthma. It may be used in decoction.

$$
\text { Order 130.-Violaces. }
$$

103. Viola. Fifty-seven species; 5, 1, L.

Viola pedata. Bird-foot violet. Off.

104. Viola cucullata. Common field violet.

105. Viola palmata. Hand violet.

106. Viola ovata. Rattlesnake violet.

107. Viola Canadensis. Canada violet.

108. Viola pubescens. Yellow wood violet.

All the violets are most excellent demulcents, and are very important in a medicinal point of view. The V. pedata and V. ovata are the most useful. I have published a long account of them, and of the efficacy of the latter in the bites of venomous reptiles, and in ophthalmias, strangury, \&c., in the American Journal of the Medical Sciences, which has been transferred to the American Journal of Pharmacy. The paper has also been published in the New York Journal of Medicine. To these works I refer the reader. I have correct paintings of the above species of violets.

\section{Order 137.-Droseraces.}

109. Drosera rotundifolia. Sun dew. Numerous species. The juice of this plant is said to destroy warts, corns, \&c.; and infused in milk it has been used for freckles and sun burns. It is supposed to be pectoral, and, in the form of syrup, is used in asthma. Raf.

\section{ORder 140.-CaryopHYLLACEA.}

110. Saponaria. Nine species; 10, 2, L.

Saponaria officinalis. Soapwort; bouncing Bet. Sec. The soapworts are diaphoretic, tonic, and hepatic. They are useful in rheuvoL. II. -57 
matism, gout, jaundice, and hepatic eruptions. They have been considered vermifuge and diuretic. Used in scrofulous and venereal ulcers. On account of its frothing, it is called soapwort. Raf.

111. Agrostemma githago. Cockle. This is a poisonous plant in wheat fields, imparting a strong and bitter taste to bread. The grain which contains much of it should, therefore, be used only for the manufacture of starch.

\section{Spergula. Ten species; 10,5 .}

Spergula arvensis. Spurry. The inhabitants of Norway and Finland use the seeds of this plant for bread, when their corn fails. Poultry are fond of them. It is nutritious to cattle, but not to horses, sheep, and goats.

\section{Order 147.-Crassulaceze.}

113. Sempervivum. Fourteen species; 11, 13. This plant is cultivated as an ornament to our houses, hence it is called houseleek. The leaves are thick and succulent. They are slightly astringent and sourish to the taste. They are externally applied as a cooling application in the recent state, bruised, to burns, stings of bees, \&c., and to other affections of the skin, ulcers, inflammation, \&c. An ointment made by boiling them in lard, is excellent in piles, chilblains, \&c.

\section{Order 153.-Chenopodiaces.}

\section{Chenopodium. Thirty-eight species; 5, 2, L.}

Chenopodium botrys. Jerusalem oak. Off. This is not the genuine worm-seed, though it possesses anthelmintic properties, like the rest of the genus. The whole of this plant possesses excellent pectoral properties. A valuable syrup is prepared from it for recent coughs. Emmenagogue, resolvent, and carminative.

115. Chenopodium hybridum. Aris, a species of hogweed. This plant is in great use in domestic practice as an emmenagogue. A tea of it is made with pennyroyal, and the patient is to drink of it ad libitum, and to soak the feet in warm water. I have seen most wonderful effects from the use of this tea; but, perhaps, it may be imputed in part to the pennyroyal which is used with it, which is a very popular emmenagogue of itself. 
Order 154.-Phytolaccaces.

\section{Phytolacca. Six species; $11,10, \mathrm{~L}$.}

Phytolacca decandra. Poke, garget, crowberry, \&c. Off. This valuable plant possesses emetic, cathartic, and narcotic properties. It is in great repute for the cure of rheumatism, the piles, cancer, and a great variety of complaints. Farmers make much use of the roots for rowels or setons, for their cattle and horses. The berries are employed in tincture. For a more particular account, see dispensatories, \&c.

\section{ORder 157.-Polygonaces.}

117. Polygonum hydropiper, or punctatum. Water pepper, smartweed, \&c.; 9, 3, L. Fifty-three species of the genus. Off. This is a biting, pungent diuretic, inflaming the tongue and skin, when applied to them. It is vermifuge, and highly stimulant. Infused in wine, it is much used in gravel. It is said to cure ulcers in the mouth, toothache, \&c. The ashes make a soap, which Cutler says has been a specific for the cure of stone in the bladder. A tea of the plant is good in coughs and colds. Cattle will not touch the plant. Snakes avoid it, and it kills fish. An infusion of it is a powerful promoter of urine. Raf. It is singular that, wherever geese are kept, this plant abounds. Formerly they roamed in Deerfield Street, and the plant covered the whole street. But, since they are not suffered to run at large, the plant is not found here.

118. Polygonum fagopyrum. Buckwheat. An infusion of this plant is useful in erysipelas, used externally and internally.

\section{Rumex. 6, 3, L.}

Rumex acetosella. Sorrel; sorrel dock. The leaves have an agreeable acid taste, and are refrigerant, antiscorbutic, and diuretic.

120. Rumex crispus. Curled dock. Off. The medical properties of the various species of dock are mildly astringent, bitter, and tonic, and also laxative. They are valuable in scorbutic and other eruptions. At one time, they were thought to be a specific in the cure of the itch, and cancers. According to Rafinesque, the roots contain sulphur, starch, oxalate of lime, \&c.

Order 173.-Pyrolacex.

121. Pyrola. Altered to Chimaphila. Seven species; 10, 1, L. 
Chimaphila maculata. Prince's pine; pipsissewa; spotted winter-green. Off. This is a most powerful diuretic, and has been extensively used in dropsy. It is also tonic, astringent, and depurative. It is much used in cutaneous eruptions, and particularly in cancerous affections, over which it has a feeble, if any, action. See Materia Medica.

122. Chimaphila rotundifolia. Round-leaved winter-green; shinleaf. The leaf, bound on old ulcers of the skin and leg, have proved successful in their cure.

123. Monotropa. Four species; 10, 1, L.

Monotropa uniflora. Pipe plant; beech drops, \&c. It is ophthalmic and nervine. The juice mixed in water, according to Rafinesque, is deemed by the Indians specific in sore eyes. The dried root is employed in epilepsy, and in the diseases of children, in doses of a teaspoonful, united with valerian. That notorious empiric, Steward, says it is a substitute for opium. According to him, it eases pain, comforts the stomach, and causes sleep and rest.

\section{ORder 175.-LOBELIACE.E.}

124. Lobelia. Ninety-five species; $5,1, \mathrm{~L}$.

Lobelia inflata. Indian tobacco; devil's pepper, \&c. Off. So much has been said and sung about this "divine remedy" of the steamers, that it is needless to recapitulate it here. The manner in which it received its appropriate English name may be found in my paper upon this plant, published in the New York Journal of Medicine and Surgery for the year 1846.

125. Lobelia cardinalis. Cardinal lobelia. This seems to possess many of the same properties with the above, but in less degree.

\section{Order 182.-Plantagenez.}

126. Plantago. Seventy species; $4,1, \mathrm{~L}$.

Plantago major. Great plantain. The leaves of this plant are used as a cooling vulnerary. The root is febrifuge and astringent, and used for diarrhœa, sore eyes, and bloody fluxes. The leaves are good for ulcers, the bites of venomous insects, and tumours. The seeds are vermifuge. The properties of

127. Plantago lanceolata, ribwort, are somewhat similar. 


\section{ORDER 186.-COMPOSITA.}

128. Arctium. Two species; 6, 1, L.

Arctium lappa. Burdock. Off. The root has been considered tonic, aperient, sudorific, and diuretic. It has been used in the form of decoction in rheumatism, and diseases of the skin. Sir Robert Walpole praised it as a gout medicine, and others have considered it an excellent substitute for sarsaparilla. The fruit, which is bitter, and slightly acid, has been used as a diuretic. (Lindley.) The wilted leaves, applied to bruises and local pains, are excellent discutients and anodynes. It was once thought to be a certain cure for cancer.

129. Leontodon. Six species; $18,1, \mathrm{~L}$.

Leontodon taraxicum. Dandelion. Off. This beautiful plant has come into much vogue in medicine, within a few years, for the cure of hepatic affections and dyspepsia. It is diuretic, and slightly tonic and aperient. It is thought to excite the languid action of the liver, and to discuss chronic enlargements of it. It is particularly adapted to all the diseases produced by the derangement of the biliary secretions. An infusion or decoction of the root, or the extract, removes obstructions of the bowels, and promotes the flow of urine. It is also useful in diseases of the skin, in dropsy, consumption, and scirrhosities of the stomach. An irritable state of the stomach forbids the use of it, or much inflammation of that organ, otherwise it may be taken freely. It is used in extract or decoction.

130. Lactuca. Twenty-three species; 18, 1, L.

Lactuca elongata. Wild lettuce. Anodyne, laxative, diaphoretic, and diuretic.

131. Prenanthes. Thirty-five species; 18, 1, L.

Prenanthes alba. Gall of the earth. This is the famous Indian cure for the bite of venomous serpents. 'It grows to a great height. The leaves are lactescent, and every part of the plant is intensely bitter.

132. Hieracium. Eighty species; 18, 1, L.

Hieracium venosum. Veiny-leaved hawk-weed. The whole plant is active and bitter to the taste. It is also vulnerary and astringent, sudorific, antiseptic, and pectoral. Schoepf and Harlan have both used the bruised leaves with success for the bite of the rattlesnake. By some, it has been called rattlesnake plantain, but erroneously. 
It has also been empirically used for the cure of hemoptysis, scrofula, amenorrhoea, and hemorrhages. It is sometimes united with bloodroot in powder for the cure of polypus in the nose.

133. Liatris. Eight species; 18, 1, L.

Liatris scariosa. Gay feather. Sec. The root has the smell of turpentine, and a bitter terebinthinate taste. It is diuretic in its properties. In decoction, it is employed in gonorrhoea and in sore throat. Also in dropsy, angina, croup, pain in the breast, gravel, \&c.

134. Vernonia prealta; $18,1, \mathrm{~L}$. Devil's bit; iron-weed. From the roots, a spirituous bitter is made, which is used in fevers in Kentucky. Good against poisons. The leaves, which are astringent, are used in sore throats.

135. Cardures altissimus. Thistle; 18, 1, L. An infusion of the roots is good in cases of salt-rheum.

136. Eupatorium. Seventy-five species; $18,1, \mathrm{~L}$.

Eupatorium perfoliatum. Thoroughwort; boneset, \&c. Off. This well-known plant is most beautifully figured by Bigelow and others, to whom I refer the reader. More virtues are ascribed to it, as a cathartic, emetie, diuretic, tonic, \&c., than to almost any other plant in use.

137. Eupatorium purpureum. Jopi root; purple boneset. Off. Elegantly painted by Barton in his Flora. It derived its name of Jopi root from an Indian in New England of that name, who cured typhus with it by powerful sweating. Eberle asserts that catarrhal fevers are cured by it by drinking a weak infusion of it on going to bed. In the dyspepsia of the aged, it is valuable. It is useful as an auxiliary to other tonics and emetics. But the principal use to which it is applied is as a diuretic, and it is, on this account, called gravel root; and we have few plants that are more efficacious in this respect. It is the queen of the meadows of the steamers.

138. Gnaphalium. One hundred and sixty species; $18,2, \mathrm{~L}$.

Gnaphalium margaritaceum. Life-everlasting. Sec. This and the G. polycephalum, silver-leaved gnaphalium, are used in infusion in affections of the breast and bowels, and in hemorrhages. Externally, they are used in fomentations; and in wounds, bruises, and internal 
pains. They are mildly astringent and vermifuge; and are good in dysentery. The gnaphaliums have different names, such as white plantain, poor robin, rattlesnake plantain, squirrel ear, \&c. They are used in cases of poisoning, and of the bite of the rattlesnake. Rafinesque says the Indians will, for a trifle, allow themselves to be bitten, and cure themselves at once with this plant.

\section{Artemisia. Seventy-two species; $18,2, \mathrm{~L}$.}

Artemisia absinthium. Wormwood. Off. Much has been said in the medical journals in favour of wormwood in cases of epilepsy. It does not, however, answer the high encomiums bestowed upon it. It is considered to be antiseptic, stomachic, detergent, vermifuge, and emmenagogue. Given in the form of infusion or powder, it has been used in all these affections. The leaves, bruised and steeped in spirit and vinegar, are valuable discutients; and I know of no more soothing application in bruises and wounds.

140. Artemisia Canadensis. Southern wood. This is also useful in the same cases. It is called mugwort.

141. Anthemis. Forty-two species; 18, 3, L.

Anthemis cotula, synonym Maruta cotula. May-weed; wild chamomile. Sec. It is a mild tonic, possessing, in some degree, the properties of the genuine chamomile. According to Dr. Ashley, in the Philadelphia Journal of Pharmacy, it is a powerful vesicant.

142. Chrysanthemum. Thirty-five species; $18,2, \mathrm{~L}$.

Chrysanthemum leucanthemum. Ox-eyed daisy; white-weed.

This is a pestilent weed in grass fields. The young leaves may be eaten in salads. When bruised, they afford a good application to scirrhous tumours. It is said that if a decoction of them be taken by a person subject to the jaundice, immediately after coming from the tepid bath, it will tend to restore his natural colour. A decoction increases the urinary discharge. It is of service in debility attended with sweating, if drank freely, and the patient is kept cool. It is used for wounds, asthma, consumptions, and tinea. It is a principal ingredient, under the name of Pissabed, in Stewart's vegetable ointment, for the cure of salt rheum, and other cutaneous eruptions.

143. Achillea. Forty-eight species. Syng. Superf., L. 
Achillea millefolium. Yarrow. It is similar in its properties to chamomile; stimulating, slightly astringent, and tonic.

144. Tanacetum. Eighteen species; 18, 2, L. lant.

Tanacetum vulgare. Tansy. Off. Vermifuge, tonic, and stimu-

145. Inula. Forty-three species; 18, 2, L.

Inula helenium. Elecampane. Sec. Stimulant, slightly tonic, and pectoral. In great use in diseases of the breast and lungs.

146. Tussilago. Twenty-one species; $18,2, \mathrm{~L}$.

Tussilago farfara. Colt's-foot. Off. Demulcent and expectorant. More extensively used by the people at large in the form of syrup, in coughs, than almost any vegetable known.

147. Erigeron. Forty-three species; 18, 2, L.

Erigeron Canadense. Canada fleabane. Sec.

148. Erigeron Philadelphicum. Philadelphia fleabane. Sec. These plants are some of our most powerful astringents. For an extensive account of their medicinal properties, see a paper published by me on the subject in the New York Journal of Medicine and Surgery for 1846.

149. Senecio hieracifolium. Fire-weed; groundsel. An ointment made from this weed is most efficacious in the piles. It is also useful in diseases of the skin, wounds, \&c., in hemorrhages, and in wounds. It is emetic in large doses.

150. Aster. One hundred and twenty species; 18, 2, L.

Aster Nova Anglix. New England aster. Our beautiful asters do not blossom here till late in the summer, or early in the fall. Their medical properties have not been sufficiently investigated. According to Dr. Lawrence, of Lebanon, N.'Y., a Shaker, this species is employed in decoction externally in eruptions of the skin, and it is also very valuable against the virulence of the poison sumach.

151. Aster cordifolius is useful as a nervine, and is preferable, in many instances, to valerian. It has been used in decoction and in- 
fusion in spirit for rheumatism. A species called squawroot has been used by old women as a partus accelerandum. The asters may be profitably employed as equivalents to valerian in nervous affections, in epilepsy, spasms, hysteria, \&c. Raf.

152. Solidago. Forty-eight species; 18, 2, L.

Solidago odora. Sweet-scented golden-rod. Off. The golden-rods are very abundant here, blossoming late in the fall; but this species is scarce. This is aromatic, stimulant, carminative, and diuretic, when given in warm infusion. An oil is obtained from it which is very pleasant, and much resembles the oil of anise. It is proper in all those cases where the latter is used. The flowers make an agreeable tea.

\section{Bidens. Twenty-one species; $18,2, \mathrm{~L}$.}

Bidens aroma. Water-beggar-tick. This is a troublesome weed in our gardens and fields. The ticks, or beggar-lice, as they are sometimes called, boiled in water and strained, mixed with syrup of sugar or honey, form a most excellent expectorant for hooping cough, other kinds of coughs, and catarrhal affections.

\section{Ambrosia. Nine species; $25,5, \mathrm{~L}$.}

Ambrosia elatior. Rag-weed; hog-weed; wild wormwood. This plant is considered to be emollient and antiseptic when used in fomentations. It is a troublesome weed in gardens and fields. Most animals, except the hog, refuse it; and, if cows eat it, it makes their milk bitter. It is said to give a bitter taste to bread when mixed with the wheat.

155. Ambrosia trifida. Called horse-weed. According to Rafinesque, it is used by the Indians to make a kind of hemp and ropes. Used in after-pains, and nervous and hysterical affections.

156. Xanthium strumarium. Sea-burdock; clot-burr. The leaves are bitter and astringent, and are useful in scrofula, herpes, and erysipelas. They dye a yellow colour.

\section{Order 180.-Stellata.}

157. Galium. Seventy-seven species; 4, 1, L.

Galium asprillum. Rough bedstraw. This has been extensively used as a diuretic, and has been employed most successfully in all 
suppressions of urine, strangury, gravel, \&c. It has also proved beneficial in scurvy, bleeding at the nose, hemoptysis, \&c. An infusion of it has been said to have cured the epilepsy and the gout. A poultice of it, also, has been used for tumours of the breast.

158. Galium aparine. Cleavers; goose grass. Sec. This plant has a bitter, herbaceous, and acrid taste. The juice is diuretic, aperient, and antiscorbutic. It is useful in the various species of dropsy, scrofula, and scurvy. The fresh plant, prepared into an ointment, or decoction, has been used externally to scrofulous swellings with success.

159. Asclepias. Fifty species; 5, 2, L.

Asclepias Syriaca. Silkweed; milkweed. Sec. This plant is anodyne, expectorant, \&c. The young shoots are edible, like asparagus.

160. Asclepias incarnata. Flesh-coloured asclepias. Sec. The western Indians use the roots in dropsy, asthma, dysentery, and as emetics. Some physicians consider the plant emetic and cathartic.

161. Asclepias tuberosa. Pleurisy root; butterfly-weed, \&c. Off. This is considered one of our most valuable expectorants, the properties of which are described in our Dispensatories and Materia Medicas.

ORDER 196.-APOCYNEA.

162. Apocynum. Eighteen species; 5, 2, L.

Apocynum androscemifolium. Common dog's-bane; bitter root; honey-bloom, \&c. Sec. This plant is emetic, tonic, syphilitic, alterative, and diaphoretic. It is most beautifully coloured, and described by Bigelow, to whom, and to the Dispensatories, I refer for further information concerning it.

163. Apocynum cannabinum. Indian hemp. Sec. It is similar in its properties to the above. Both these plants, instead of being on the secondary list in our Pharmacopœias, should be officinal.

Order 197.-Gentranacex.

164. Gentiana. Sixty-one species; $16,10, \mathrm{~L}$.

Gentiana saponaria. Soapwort gentian; blue bells. 
165. Gentiana saponaria. Fringed gentian. All the gentians are beautiful plants, and they are all tonic, bitter, corroborant, cathartic, and are excellent substitutes for foreign gentian. They invigorate the stomach, and are useful in dyspepsia, and in debility of that organ. They are extensively employed in the Southern States in various kinds of fevers, pneumonias, \&c., as tonics. In large doses, they are purgative.

166. Menyanthes. Six species; $5,1, \mathrm{~L}$.

Menyanthes trifolia. Buck bean; water shamrock. In large doses, this plant has a bitter, tonic, and cathartic property. It is also stomachic and febrifuge, anthelmintic and diuretic. In decoction, it is used in dropsy, rheumatism, worms, \&c. It was formerly a good deal used, then neglected, but now coming into vogue again.

\section{Order 199.-Convolvulaces.}

167. Convolvulus. One hundred and fifty species; $5,1, \mathrm{~L}$.

Convolvulus arvensis. Field bind-weed; wild potato. This has sometimes been used as a substitute for jalap, but it is a very feeble one. It is supposed to be somewhat diuretic, and it has been used in cutaneous complaints. Forty grains of the powder purge gently.

168. Cuscuta. Eleven species; 5, 2, L.

Cuscuta Americana. Dodder. This plant is bitter and subastringent. It dyes red. It is also stomachic, febrifuge, and antiscrofulous. It is used in decoction for agues.

\section{Order 110.-Orobancheas.}

169. Orobanche. Twenty-four species; 14, 2, L.

Orobanche Virginiana. Beech drops; cancer root. Sec. This plant is bitter, nauseous, and astringent. It loses, in some measure, these powers by drying. It has been employed in bowel affections; but its virtues mainly depend upon its supposed efficacy in curing cancerous ulcerations; and it was for a long time supposed to be a principal ingredient in the secret remedy of Dr. Martin, for the cure of cancer. But Dr. Rush proved the powder of Dr. Martin principally to consist of arsenic. This plant is also powerfully astringent, and has been used for erysipelas, and canker in the throat. It is used at the West as a specific in syphilis and gonorrhøa. It is also employed for hepatic affections, diarrhœea, and dysentery. (Synonym, Epiphegus Americana.) 
170. Orobanche uniflora. Small cancer roots. The properties of this are similar to the above.

171. Scrophularia. Twenty-eight species; 14, 2, L.

Scrophularia Marylandica. Figwort. This plant has a rank smell and bitter taste, which seem to indicate that it possesses some active medicinal properties. It is vulnerary and resolvent, and is much used in the Northern and Middle States. It is good in ulceration in the form of poultices. By washing with a decoction of it, swine infected with the scab, are cured, and also dogs.

172. Chelone. Four species; 14, 2, L.

Chelone glabra. Snake head. The valmony, I believe, of the Thompsonians. This plant is a good corroborant, and should be classed with our tonics. It is most intensely bitter to the taste. It may be used in strong infusion; useful in dyspepsia, loss of appetite, and general debility. See an interesting article on this plant by Dr. J. A. Allen, of Middlebury, Vermont, in the Boston Medical and Surgical Journal; see also Rafinesque, who gives a long account of it from Dr. Lawrence, of New Lebanon, Mass.

173. Leptandra Virginica. Bowman's root; physic root; Culver's physic. The plate of this plant, as given by Rafinesque, exactly resembles the spiræa tomentosa, though the properties are opposite. The former (leptandra) is powerfully cathartic, and the spiræa is powerfully astringent. The root is the part employed. The roots, according to Rafinesque, lose much of their virulence by drying, and a drachm of the powder becomes an uncertain purgative, while, when fresh, they are drastic and dangerous in substance, and are said to produce bloody stools, dizziness, vertigo, and abortion.

174. Pedicularis. Thirty-four species; $14,2, \mathrm{~L}$.

Pedicularis Canadensis. Common lousewort. It is vulnerary, and sometimes called heal-all. The Indians used to cure the bite of the rattlesnake with this plant.

\section{ORder 213.-SOLANACEE.}

175. Solanum. One hundred and fifty-six species; 5, 1, L.

Solanum dulcamara. Bittersweet; woody nightshade; poison bittersweet. This must not be confounded with the celastrus scan- 
dens, or waxwork, which is universally called bittersweet by the common people. The solanum dulcamara is narcotic, as are all the solanums, diaphoretic and diuretic. Bigelow has painted it elegantly in his splendid Medical Botany.

176. Solanum nigrum; variety Virginianum. Common nightshade; garden nightshade. A light decoction of the leaves, taken at bedtime, occasions a free perspiration, increases the urine, and produces a purgative effect the following day. The leaves applied externally, abate inflammation and assuage pain. The leaves are poisonous, and to poultry they are immediately fatal. Externally, it has been found a useful discutient and anodyne in various affections of the skin, tumefactions of the glands, ulcers, and disorders of the eyes. With the Arabians, it is a common application to burns and ulcers, and Ray speaks highly of it in indurations of the breast. Mr. Gattaker has recommended, in a publication on the subject, its internal use in old sores, scrofulous and cancerous ulcers, cutaneous eruptions, and even in dropsies; one grain of the dried leaves, he says, infused in an ounce of water, sometimes produced considerable effect; in a dose of two or three grains, it seldom failed to evacuate the first passages, and to increase sensibly the discharge from the skin, or by the kidneys; and not unfrequently it occasions headache, giddiness, dimness, and drowsiness. The flowers smell like musk.

177. Physalis alkekengi. Ground cherry; winter cherry. The berries are diuretic and sedative. They are acrid and bitterish; but children are nevertheless fond of them.

178. Hyoscyamus. Eight species; 5, 1, L.

Hyoscyamus niger. Black henbane; stinking nightshade. Off. This is a highly narcotic, but most valuable medicine in the hands of judicious physicians. In many respects, it is superior to opium, as it is not apt to leave the bowels in a costive state. See Dispensatories.

179. Datura. Eight species; 5, 1, L.

Datura stramonium. Thorn apple; apple peru; Jamestown weed, \&c. Off. This valuable anodyne and narcotic may also be found well described in all our standard materia medicas. 
180. Verbascum. Twenty-seven species; $5,1, \mathrm{~L}$.

Verbascum thapsus. Mullein. Off. This plant is slightly narcotic, anodyne and emollient. It was in early use by the fathers of our profession, and was much extolled by Woodville, Home, Bergius, Withering, and many others, in diarrhœea, dysentery, piles, \&c.

\section{Order 220.-VVerbenacez.}

181. Verbena. Twenty-one species; $14,1, \mathrm{~L}$. Sec.

Verbena hastata. Purple vervain. Sec. The vervain was formerly used in sacrificial rites, and in the superstitions of the day. In later times, it has been used as a cataplasm, by which the most severe and obstinate cases of cephalalgia are said to have been cured. It is bitter, emetic, and expectorant, and is much used as an ingredient in syrups for coughs, consumptions, \&c. The steamers think this plant almost equal to the lobelia as an emetic.

182. Verbena urticifolia. Nettle-leaved vervain. Sec. This plant has been employed with advantage in poisoning from the poison sumach. It is prepared by boiling it with the inner bark of the white oak. Thus prepared, it is used in erysipelas.

\section{Lycopus; 2, 1, L.}

Lycopus Virginicus. Water agrimony; bugle. Sec. In a paper, upon this subject, published in the New York Journ. of Med. and Surg. for 1846, I have spoken of this plant as being one of the most valuable styptics we possess in our vegetable materia medica.

\section{Monarda. Eight species, 2, 1, L.}

Monarda oblongata. Mountain balm; or, mountain mint. Off. The monardas are allied to the melissas. They are tonic, febrifuge, nervine, antiseptic, and anti-emetic.

\section{Hedeoma. Three species; 14, 1, L.}

Hedeoma pulegioides. Pennyroyal; squaw mint. Off. This is a stimulating, aromatic carminative. It is a most powerful emmenagogue, and very much in popular use for suppression of the menses.

186. Collinsonia. Four species; 2, 1, L.

Collinsonia Canadensis. Horse-balm; horse-weed; rich-weed, \&c. The whole plant has an aromatic, balsamic smell, somewhat resembling that species of sage called herb clary. It is carminative 
and vulnerary, corroborant and diuretic, warm and stimulating. It is used in the form of poultice for wounds, sores, bruises, \&c. In infusion, it is taken for colic, cramps, headache, indigestion, \&c. The whole plant is used both green and dry. Schœpf extols it in lochial colic, bites of snakes, rheumatic pains, in strong friction with the leaves. Dr. Mease says the root infused in cider has cured the dropsy. The decoction is good in the sore backs of horses.

187. Glecoma. Two species; $14,1, \mathrm{~L}$.

Glecoma hederacea. Gill; grow by the ground; ground ivy. Sec. This is tonic and stimulant, and useful in affections of the lungs and kidneys. It is also somewhat aperient; it is pectoral and ophthalmic ; used for debility of the viscera, for coughs, obstructions, and for cleansing abscesses in the kidneys and lungs. It has been employed in jaundice, the hypochondriac disease, colic, and asthma. As a sternutatory, it has been employed in headache.

188. Hyssopus nepetoides. Four species; $14,1, \mathrm{~L}$. Off. It is a warming stimulant, and slightly aromatic. An infusion of it is in high repute in coughs and chronic affections of the lungs. It is very diaphoretic and expectorant, and it is in great demand in fevers and acute complaints.

189. Melissa. Eleven species; 14, 1, L.

Melissa cataria. Catnip; catmint. Sec. This is altered from nepeta to melissa. An infusion of the plant is deemed by some to be almost specific in chlorosis. Cats are very fond of it, and eat it with avidity. It is carminative and stimulant, and much used in the flatulence of infants. Miller says that, if it be raised from seeds, cats will not meddle with it. In support of this opinion, he quotes an old saying: "If you sow it, the cats will know it; if you set it, the cats will eat it." It is said to have been advantageously administered in amenorrhœa. Lindley.

\section{Leonorus. Eight species; 14, 1, L.}

Leonorus cardiaca. Motherwort. A decoction of this plant has similar properties with valerian, and is used in nervous and hysterical affections. It is stimulant and pectoral, and is employed for coughs, catarrhs, and heartburn.

191. Chenopodium. Synonym, Cunila. Five species; 14, 1, L. 
Cunila mariana. Wild basil; thyme; stone mint, \&c. The whole of this plant is a pungent, warm aromatic, similar in its properties to pennyroyal. It is useful in exciting perspiration in colds, in the commencement of fevers, to promote the menses, for flatulent colic, and in all those cases where the mints are employed. Its virtues reside in an essential oil. The Indians, says Rafinesque, use it for wounds; to expel a dead child. It kills rattlesnakes by holding it to the nose by a stick.

\section{Marrubium. Fifteen species; 15, 1, L.}

Marrubium vulgaris. Horehound. Sec. This plant is tonic, with a rank smell, and bitter taste. It is emmenagogue, vermifuge, and deobstruent, and is much used in humoral asthma, dysmenorrhœa, and in affections of the kidneys, menstrual obstructions, in cachectic diseases, and phthisis. It is more used in domestic than in regular practice. It is the basis of the negro Cæsar's remedy for the bites of snakes.

\section{Prunella. Nine species; $14,1, \mathrm{~L}$.}

Prunella Pennsylvanica. Self-heal; heal-all. Sec. It has a bitter, austere taste, and was formerly much used in diarrhœa, hemorrhages, \&c., and for a gargle in sore throats. By the common people it is used in the form of the bruised leaves, for fresh wounds. As it is slightly astringent, it is used in broths and apozems for bleeding at the lungs, and other hemorrhages.

194. Teucrium. Seventy-three species; $14,1, \mathrm{~L}$.

Teucrium Canadense. Wood-sage; germander. This plant is aromatic, bitter, tonic, stimulant, emmenagogue, \&c., and useful in hematuria, gout, rheumatism, and chlorosis.

195. Mentha. Thirty-three species; 14, 1, L.

Mentha piperitis. Peppermint. Off.

\section{Mentha viridis. Spearmint. Off.}

197. Mentha borealis. Horsemint; cornmint. Off. All the mints are warm aromatic stimulants, and are useful in all those cases where aromatic stimulants are required. The mentha borealis is said to prevent the coagulation of milk; and when cows eat largely of it, which they do sometimes at the end of summer, their milk can 
hardly be made into cheese. The plant, bruised and applied to a woman's breast, when it is caked from redundance of milk, will subdue the inflammation, and cause the milk to flow in a short time. I have been more successful with this, in this complaint, than with any other remedy.

\section{Pyenanthemum. Fifteen species; $14,1, \mathrm{~L}$.}

Pyenanthemum incanum. Mountain mint. This plant is similar in all respects, in its properties, to the pennyroyal.

199. Scutellaria. Twenty-four species; 14, 2, L.

Scutellaria lateriflora. Scull-cap; mad-dog weed. Sec. I do not feel disposed to canvass the mooted question, at this time, whether this plant is efficacious in the cure of hydrophobia. Many highly respectable physicians have believed in its efficacy in this complaint, while others have believed it to be inert. According to Rafinesque, the dried plant gave one-fourth of soluble matter, and a very active extract. The substances found in it by Cadet were: 1. Yellow green oil, fixed and soluble in ether. 2. A bitter principle, soluble in water, alcohol, and ether. 3. Chlorophylle. 4. A peculiar velatile matter, smelling and tasting like the principle of antiscorbutic plants. 5. An essential oil. 6. Albumen. 7. A sweet mucous substance. 8. A peculiar astringent principle. 9. Lignin. When burnt, the ashes afford the chloride of sada, and seven other salts. It is, therefore, preposterous to deem such a plant inert. It is, says he, tonic, astringent, antispasmodic, and anti-hydrophobic, at least. The steamers consider it their grand antispasmodic.

200. Ocymum. Basil. Similar in its properties to the mints, pennyroyal, \&c.

\section{Order 222.-BORAGINEx.}

201. Cynoglossum. Thirty-five species; 5, 1, L.

Cynoglossum officinale. Hound's tongue. Sec. Called hound's tongue from the shape of the leaves. The root and leaves have an odour like mice, and it is said that rats will not infest a barn where this plant is deposited. Many writers consider this plant poisonous, while others think it inert. The point is unsettled. It has been employed as a demulcent and sedative in spitting of blood, coughs, catarrhs, dysentery, diarrhœa, \&c.; likewise in burns, scrofulous tumours, ulcers, \&c. The leaves, smoked like tobacco, are narcotic.

VOL. II. -58 


\section{Sub-Class II. EXOGYNæ⿸}

\section{Tribe 2. Gymnospermæ.}

\section{Order 229.-Alismacete.}

\section{Alisma. Ten species; $18,13, \mathrm{~L}$.}

Alisma plantago. Great water plantain. This plant formerly obtained great celebrity as a specific in hydrophobia. Most modern writers think it is not entitled to the high encomiums bestowed upon it by the Russian physicians. So long ago as the days of Dioscorides, this plant was considered efficacious as an antidote to opium. The whole plant is irritant. The fresh root is acrid and nauseating, and, applied to the skin, will often excite vesication. It loses this quality by drying; and, like the arum, becomes nutritious. It has also been considered useful in diseases of the urinary organs.

\section{ORder 239.-Iridaces.}

203. Iris. Fifty-nine species; 3, 1, L.

Iris Virginica. Flower de luce. This plant possesses cathartic properties. It is acrid and stimulant. The expressed juice of the roots, in a dose of sixty or seventy drops, will frequently operate, when the drastric cathartics have failed. It is also diuretic and emetic. An ointment of it is said to cure the itch and other affections of the skin; and it is good for inflamed breasts, indolent ulcers, \&c.

ORDER 240.-ORCHIDEA.

204. Orchis. Eighty-seven species; 19, 2, L.

Orchis fimbriata. Gay orchis; twin-root orchis. From the orchis a salep is made. The roots of this species are vermifuge, and the powder is said to kill worms by touching them with it.

\section{Arethusa. Eight species; 19, 2, L.}

Arethusa bulbosa. Arethusa. Schoep says that the bruised bulbs are useful for the toothache; and they are of service in poultices for tumours.

206. Cypripedium. Ten species; 19, 2, L.

Cypripedium luteum. Yellow ladies' slipper; American valerian; 
nerve powder. This plant is much in vogue with the quacks and steamers. They say it possesses properties equal, if not superior, to foreign valerian. They dry the root and powder it fine, and keep it in tight stopped bottles. They call it nervine, and use it in nervous affections. They also employ it to assist the operation of their emetics, in doses of half a teaspoonful. It is said to quiet the nerves, prevent spasm, and produce sleep without stupefying. When a person cannot sleep, they put a teaspoonful of this powder into a teacupful of pennyroyal tea, and drink it warm on going to bed at night, and they say it will produce quiet and refreshing sleep. The root is the only part used. The roots are pungent and mucilaginous.

\section{Cypripedium spectabile, gay ladies' slipper, and}

208. Cypripedium humile, love ladies' slipper, are possessed of similar properties. They are all said to be nervine, antispasmodic, and sedative. They are used in hemicrania and nervous fevers. In many cases, the steamers think they are preferable to opium. Their power is increased by combining them with tonics. The Indians call the cypripediums pappoose, shepherd's purse, squaw moccason. They say its principal use is for women. It relieves them when they are obstinate in their monthly courses, and facilitates the birth of children.

\section{Order 245.-Melanthacez.}

209. Helonias dioica. Devil's bit. The decoction of the root of this plant is used for colic. It is thought to be anthelmintic, bitter, and tonic.

\section{Veratrum. Nine species.}

Veratrum viride. Green hellebore. Off. This plant possesses properties somewhat like the black hellebore of the shops. It is acrid, nauseous, emetic, sternutatory, diuretic, \&c. I have used it with success, combined with other diuretics, in dropsy. A few grains, snuffed up the nose, proves powerfully sternutatory; and I have often employed it in cases of periodical headache, attended with dryness of the nostrils. It is prescribed in mania, psora, \&c., but must be used with caution.

211. Allium. One hundred species; $6,1, \mathrm{~L}$. 
Allium Canadense. Wild onion. The properties of this plant are similar to onions, garlic, \&c.

\section{Order 245.-SMILACEA.}

212. Smilax. Forty-nine species; 21, 6, L.

Smilax rotundifolia. Green briar. An infusion of this is said to be of service in mercurial salivation, in chronic rheumatism, and affections of the skin.

213. Smilax sarsaparilla. Sarsaparilla. This possesses the same properties as the sarsaparilla of commerce, but in a more feeble degree.

214. Convallaria. Twelve species; 6, 2, L.

Convallaria multiflora. Great Solomon's seal. Sec. The root of this plant has been efficaciously used in the cure of the piles. Take one pound of the green root, or four ounces of the dry root. Boil in one quart of water to one pint; strain, and add a pint of molasses; simmer, and take a wineglassful three times a-day.

215. Trillium. Six species, according to the New Edinburgh Encyclopedia. Thirty-five, according to Rafinesque; 6, 3, L.

Trillium erectum. Wake-robin; beth.

\section{Trillium cornuum. Nodding wake-robin.}

217. Trillium pictum. Painted trillium. Rafinesque says he was the first to introduce this species of plants into the materia medica. His Medical Flora was published in 1830, when he announced the fact, as he called it. It has been in use here as an astringent more than forty years; and I consider it one of our most valuable medicines in that class. It should certainly be ranked as officinal. Henry introduced it in his Medical Botany as long ago as the year 1812; and I believe earlier. In 1819, I published a full account of its virtues in the New England Journal of Medicine and Surgery; and in 1846, in the New York Journal of Medicine.

\section{Order 251.-LILTACEe.}

218. Erythronium. Two species; $6,1, \mathrm{~L}$.

Erythronium Americanum. Adder's tongue; dog-tooth violet. Off. The whole plant contains fecula, mucilage, and resin, and an acrid, 
volatile principle. When dry, the root is farinaceous. The bulbs of the root and the leaves are emetic, emollient, and suppurative, nutritive when dry, possessing many of the properties of lilies. The dose of the green bulb is twenty-five grains for an emetic effect. As it loses its activity by drying, it is an uncertain emetic. Bigelow proposes trying it as a substitute for colchicum. Steward says it is one of the most certain remedies in mercurial sore mouth of any yet discovered. I have not much faith in its efficacy in this respect. It is diuretic, and useful in dropsy.

\section{ORder 255.-TyPHIACER.}

219. Typha. Six species; 20, 3, L.

Typha latifolia. Cat-tail flag; reed-mace. The roots are esculent, and febrifuge. Their fecula yields a tenth of the whole root, similar to salep. Boiled in milk, it forms a porridge equal to that of genuine arrowroot, and useful in diarrhoeas, dysenteries, and in affections of the mucous membrane of the stomach and bowels.

\section{ORDER 256.-AROIDEE.}

220. Arum. Twenty-eight species; 20,13, L.

Arum triphyllum. Wild turnip. Sec. The whole plant is violently acrid, and very caustic to the tongue, but not to the skin. It loses its causticity, in a great measure, by drying. It is stimulant, expectorant, carminative, and diaphoretic. The fresh root is too caustic to be taken internally. The dried root is often mixed with honey, for an expectorant, in teaspoonful doses. It is good in aphthæ, in flatulence, and in cramps. It stimulates the stomach.

221. Arum dracontium. Gum dragon. Possesses similar properties.

222. Cella. Three species; 20, 13, L.

Calla palustris. Swamp robin; water arum. The properties of this are likewise similar to the arums.

223. Ictodes foetida. Synonym, Pothos foetida. 4, 1, L. Off. This powerful stimulant plant is so accurately described by all writers on the Materia Medica that I need not refer to them.

224. Acorus. Two species; $6,1, \mathrm{~L}$. 
Acorus calamus. Sweet flag. Sec. The root is the only part used, and it is highly aromatic and tonic.

\section{ORDER 000.-CinchONACEe.}

225. Cephalantus occidentalis. Button-bush; 4, 1, L. The whole of this plant is bitter, especially the bark of the root. It is tonic, diaphoretic, and febrifuge. All the parts of the plant are used. The flowers and leaves make a fine, fragrant syrup, which is tonic and laxative, and is useful in intermittent fever, and in relaxed bowels.

\section{Cornus. Fourteen species; 4, 1, L. N. 0, Cornacex.}

Cornus forida. Dogwood; box-tree. The properties of this article are astringent and tonic, and it has long been used as a substitute for Peruvian bark; and even cornine has been prepared from it, like quinine. It may be administered for the same purposes, and in the same dose with quinine.

\section{Cornus sericea. Swamp dogwood. Sec. And}

228. Cornus circinea. Round dogwood; possesses similar properties with the above.

229. Mitchella. N. 0.; 4, 1, L. Sixteen species.

Mitchella repens. Creeping chequer berry; two-eyed chequer berry. This plant is sometimes mistaken for the Gaultheria procumbens, they both being evergreen; but this is a creeping plant, and that erect. This has no aromatic property, while the Gaultheria is very spicy. This is a most valuable diuretic, and is extensively used for the cure of dropsy. The red berries are mildly astringent, and are used, also, for the cure of diarrhœa. The Indian Dr. Louis uses it in combination with the Spiræa alba, a species of hardhack, for the cure of salt rheum.

230. Lysimachia. Twenty species.

Lysimachia racemosa. Loose strife. This plant is slightly astringent, stomachic, and expectorant. It is good for coughs and colds, and to improve the appetite.

$$
\text { N. O.-CAPRIFoliacez. }
$$

231. Triosteum. Three species; $5,1, \mathrm{~L}$. 
Triosteum perfoliatum. Horse ginseng; fever root. The root is cathartic, and in large doses emetic. It is thought by some to be diuretic. The bark of the root is the part employed. It is useful in fevers, pleurisies, agues, \&c. Dose: twenty or thirty grains of the powder operate as a cathartic.

\section{N. O.-ANACARDIACER.}

232. Rhus. Forty-two species; 5, 3, L.

Rhus vernix. Poison sumach; swamp sumach; dogwood. Off.

233. Rhus toxicodendron. Poison sumach. These are some of the most poisonous vegetables known in our country, hardly excepting the poison lobelia.

234. Rhus copalinum. Common sumach.

235. Rhus glabrum. Smooth sumach. Sec. These plants are valuable astringents. An infusion of the berries makes an excellent gargle for aphtha. The decoction of the bark has been successfully applied in cases of diarrhœa and dysentery.

\section{N. 0.-ХаNтhoxylaces. $21,5, \mathrm{~L}$.}

236. Xanthoxylon fraxineum. Prickly ash. See Aralia spinosa.

N. O.-Celartraces.

237. Celastrus scandens. False bittersweet; wax work. This plant is extensively used in the form of ointment, as an excellent discutient in all indolent indurations, and swellings, both acute and chronic; for cakes in the udders of cows, it has been more extensively used than any within my knowledge. I have used it successfully for prurigo labialis with more relief than any other application. It is good in burns, and excoriations. It is diuretic, and a decoction of the bark of the roots has been successfully used in strangury and gravel. It is said to be antisyphilitic and emetic.

\section{N. O:-Rhamnacea.}

238. Ceanothus Americana. 5, 1, L. New Jersey tea; Sec. Nine species of Ceanothus. This is an elegant astringent, and was used by the soldiers in the Revolutionary war as a substitute for tea. 
N. O.-Amentacee.

239. Celtis. Fifteen species; 5, 1, L.

Celtis crassifolia. I have seen but a single tree of this species in Massachusetts; there may be many more. I believe it is a native of the South and West. The bark is anodyne and refrigerant. The berries, which are sweet and sub-astringent, are good to eat, and are useful in dysentery.

\section{N. O.-Amentacez.}

240. Alnus. Four species; 20, 4, L.

Alnus ferrulata. Alder. Sec. The leaves are bitter and astringent. When applied to the female breast, they are said to repel the milk. The bark is a most valuable astringent. I have published an account of its efficacy in hæmaturia, in the New York Journal of Medicine for 1846. Dr. Hilmich, of Zanesville, Ohio, in the same journal, for 1847, extols it for cancerous ulcerations, ill-conditioned ulcers, scrofulous affections, syphilis, and hepatic eruptions.

\section{N. O.-UMBELLIFER \&.}

241. Heracleum. Eleven species; 5, 2, L.

Heracleum lanatum. Masterwort; cow parsnep. Sec. See the article Smyrnium, and the controversy on the subject between Dr. Partridge and Dr. Thacher. This is a warm, stimulating carminative, and has been successfully employed by Dr. Orne, of Salem, in cases of epilepsy.

\section{Ligusticum. Eighteen species; 2, 5, L.}

Ligusticum levisticum. Smellage. Sec. The whole plant is most aromatic and pungent. It possesses a resin similar to opoponax. All the parts of the plant are used; but the seeds are the most active. The properties of this plant are similar to angelica. It has been employed as an emmenagogue, carminative, and diaphoretic, in form of infusion. W. and B.

\section{N. O.-CAPRIfOLIACEx.}

243. Lonicera. Twenty-two species; $5,1, \mathrm{~L}$.

Linicera sempervirens. Honeysuckle. The ripe berries of this beautiful plant are strongly purgative. The leaves and flowers are bitterish, mucilaginous, and detersive. A syrup is prepared from them for sore-throat and irritability of the lungs. 


\section{N. O.-CAPRIFOLIACER.}

244. Sambucus. Six species; 5, 3, L.

Sambucus nigra. Black-berried elder. Off. Diuretic and laxative. The green bark, infused in wine, is excellent in dropsy.

245. Sambucus rubra. Red elder. The bark of this species, in decoction, is one of the most valuable hydragogue cathartics which we possess. In large doses, it is emetic.

\section{N. 0.-Rhamnace五.}

246. Rhamnus. Forty species; 5, 1, L.

Rhamnus catharticus. Off. Buckthorn. Mildly cathartic, hydragogue, and emmenagogue. Used in dropsy, rheumatism, gout, and hepatic eruptions.

\section{N. O.-Ulmacea.}

247. Ulmus fulvæ. Off. Slippery elm. Seven species of ulnus. Rafinesque says, "A specific to procure easy labour to pregnant women, by using the tea for two months previous; well known to Indian women, whose easy parturition has often been noticed; now becoming in general use." I wish it might prove generally true among civilized women. One of the very best demulcents known.

$$
\text { N. O.-Boraginacer. }
$$

248. Symphitum. Six species; 5, 1, L.

Symphitum officinale. Comfrey. Sec. This plant contains a mucilage of a slightly astringent taste, almost inodorous. It contains mucilage and tannin. It was formerly in great use as a vulnerary; but not in much vogue now. Much used in coughs and strengthening syrups, and in female weaknesses.

\section{N. O.-NARCISSUS.}

249. Hypoxis. Eighteen species; 6, 1, L.

Hypoxis erecta. Yellow-eyed grass; star grass. This beautiful little grass is vulnerary and febrifuge. The roots are sometimes eaten. They are used in long-standing ulcers and agues.

$$
\text { N. O.-Rhamnaces. }
$$

250. Prinos. 6, 1, L.

Prinos verticillatus. Black alder; red-berried alder. Sec. The inner bark is emetic and cathartic, tonic and astringent. It is used 
in intermittent and other fevers, dropsies, hepatic eruptions, jaundice, foul ulcers, \&c., either in powder, decoction, tincture, or poultice. The red berries, which adorn the shrub during the winter, are purgative and vermifuge, tonic and bitter.

\section{Caulophyllum. 6, 1, I.}

Caulophyllum thalictroides. Blue-berry cohosh. This plant is different from the actæas, which are sometimes called cohosh, and must not be mistaken for them. The root is the only part employed. It is demulcent, antispasmodic, sudorific, and emmenagogue. The Indians and quacks recommend it in colic, sore throat, rheumatism, dropsies, \&c. It partakes of the nature of ginseng and seneka. The Indian women use it successfully in cases of lingering parturition. It appears to be peculiarly suited to female complaints. It is a powerful emmenagogue, and promotes delivery, the menstrual flux, and dropsical discharges. It should be given in warm infusion, decoction, tincture, syrup, or cordial. It contains gum, resin, and oil. Raf.

252. Cimicifuga racemosa. Cohosh, black snakeroot, may be the synonym for the above, as its properties are similar.

\section{N. O.-LILIACEA.}

253. Uvularia. Eleven species; 6, 1, L.

Uvularia perfoliata. Bellwort. The roots, when fresh, yield a fine mucilage. It is used, like the cypripedium, as a nervine. It is said to cure sore throat, by chewing it and swallowing the saliva. It is said, also, to cure the bite of the rattlesnake, like the hieraceum. It is used in cases of wounds, sores, \&c. The young shoots are edible like asparagus; and the dried roots, when cooked, are also edible.

\section{N. O.-AcERA.}

254. Acer montanum. Rock, or sugar-maple. Twenty-two species of acer; 8, 1, L. This species is most valuable on account of the sugar which it yields, which has become almost one of the staple commodities of the United States.

255. Acer rubrum. Soft maple; red maple; meador maple. This species is also used in making sugar, but its sap is more aqueous, and yields less sugar. A good ink is made by boiling it with cop- 
peras (sulphate of iron). A wash for sore eyes is made by the Cherokee Indians, by boiling the inner bark with water. I have seen it used successfully.

256. Acer striatum. Striped maple bush; cancer bush, \&c. This is a handsome tree, which seldom grows larger than a shrub. The bark is handsomely striated with green and brown. The bark of this tree has obtained some reputation as a remedy in cancerous and other eruptions, by drinking and washing with a decoction of it. But little dependence can, however, be placed upon it. The leaves have been used as a local application to the inflamed breast.

\section{N. O.-Thymelacez.}

257. Dirca. 8, 1, L.

Dirca palustris. Leather-wood; moose-wood. Sec. The berries of this plant are thought to be poisonous. The bark is tough as leather, and it is used by the Indians instead of ropes ; it is emetic, cathartic, rubefacient, and epispastic; the bark and roots are the parts employed; its properties are similar to mezereon and seneka, but it is more powerful than the latter.

\section{N. O.-ERICEA.}

258. Arbutus. Two species; 10, 1, L.

Arbutus uva ursi. Bearberry; mountain box. Off. Diuretic, and slightly astringent and tonic. It is used in nephritis, gravel, catarrhs, strangury, leucorrhoea, \&c. It has been employed somewhat extensively in consumption, checking hectic fever.

259. Gaultheria. Six species; 10, 1, L.

Gaultheria procumbens. Off. Partridge berry; chequer berry; mountain tea; grouse berry; dewberry; spice berry; teaberry; red berry; winter green; red berry tea; ground berry; ivy; ground holly; hill berry; box berry. No less than fifteen common names for one plant. This shows how extremely arbitrary are our common English or vulgar names for plants. This is a warm, stimulating aromatic, the properties of which are well known.

260. Kalmia. Five species; 10, 1, I.

Kalmia latifolia. Broad-leaved laurel. Sec. The leaves are poisonous, and narcotic in their operation. They are extensively used in medical practice. An account of the uses of the plant may 
be found in our Materia Medicas, and a beautiful plate and description in Bigelow's Medical Botany.

261. Kalmia angustifolia. Narrow-leaved laurel; low laurel. The honey extracted from this, and the other species of laurel, by bees, is poisonous. The medical properties of this species are somewhat similar to the above. When the tribe of Indians from Canada were here in 1837, Louis Watso, their doctor, gave me an account of the principal medical plants which they used in their practice. $\mathrm{He}$ said that a plaster made by boiling this plant to a salve, applied to the affected part, would cure the rheumatism. See my manuscript, Medical Botany, page 71.

262. Ledum. Three species; 10, 1, L.

Ledum latifolium. Labrador tea; marsh tea. Sec. This plant has been used as a substitute for China tea, but it is a good deal stronger. The leaves are bitter, cephalic, pectoral, and exanthematic. Good in cutaneous eruptions, leprosy, \&c., in strong decoction. It is said to kill lice, insects, \&c.

263. Rhododendron maximus. Rosebay; mountain laurel. This beautiful plant is very scarce in Massachusetts. It is found at Plainfield, Hampshire county. It is beautifully figured and described by Bigelow. The bark and leaves are astringent. The bark is stimulant; used in rheumatism and gout. The leaves are poisonous to cattle.

\section{N. O.-FABACEE.}

264. Podalyria. Synonym, Baptisia sophora. 17 species; 10, $1, \mathrm{~L}$.

Podalyria tinctoria. Indigo weed. Sec. This plant is emetic and cathartic. When formed into an ointment, it cleanses foul ulcers, and is of service in inflammatory tumours, and irritable ulcers. The plant placed in the harness keeps flies from horses.

265. Vaccinium. Forty-three species; 10, 1, L. Whortleberries; huckleberries. These are pleasant fruits, blue, or black, slightly astringent, cooling, and diuretic. They are used extensively, either raw or cooked, as articles of food. They are employed in diarrhoea, bilious fevers, dropsy, and scorbutic affections. The 
leaves are astringent, and tan leather. A tea is made of them for sore mouth.

\section{N. O.-Portulaccee.}

266. Portulaca. Eight species; 11, 1, L.

Portulaca oleracea. Common purslane. Sec. This plant grows in our gardens, and is a valuable esculent. It has been considered diuretic and vermifuge. It is refrigerant and corroborant, but mild. Used in urinary complaints, and for ulcers in the mouth. A cooling ointment is made from it for sore lips and nipples.

\section{N. O.-Cistaceer.}

267. Cistus Canadensis. Rock rose; 13, 1, L. It has been useful in the treatment of scrofula, in decoction, and in cataplasm.

\section{N. O.-SCrophularea.}

268. Antirhinum. Eighty-two species; 14, 2, L.

Antirhinum linaria. Toad flax. This plant was formerly in great repute as a purgative and diuretic, but it is less used than formerly. In the form of ointment prepared from the leaves, there can be no doubt that it is highly efficacious for the cure of piles. It relieves the pain and irritation of the hemorrhoidal tumours, when rubbed upon them. The ointment is also useful in diseases of the skin. The leaves have been recommended in dropsies, on account of their diuretic qualities. The expressed juice mixed in milk is a poison to flies, and the smell of the flower also kills them. One species, the A. cymbellaria, by mixing the dry plant with sugar, cured diabetes in Hindostan.

\section{N. O.-Amaranthaceg.}

269. Amaranthus melancholicus. Thirty-seven species. Prince's feather; 20,5, L. This plant is used for emollient poultices in England (Lindley). In strong decoction, it has proved efficacious in arresting uterine hemorrhage, when other powerful styptics have failed. Many species of amaranth have been cultivated in our gardens for the beauty of their flowers. They are boiled and eaten like pot herbs.

\section{N. O.-Amentace $\mathbb{R}$.}

270. Betula. Seventeen species; 20,13, L.

Betula lenta. Sweet birch; cherry birch; black birch ; mount- 
ain mahogany. The wood is much used by cabinet-makers; and it admits of a very high polish. The bark affords a pleasant, aromatic spice, like the chequer berry. It is pectoral, diuretic, and stimulant. It is good for colds, coughs, and affections of the breast. Used by empirics in the form of tea, from the twigs, for obstruction of perspirations, and other kinds of obstructions ; and for disorders of the bowels. A good sugar is made from the sap.

271. Betula populifolia. White birch. The inner bark is astringent, and has been employed in intermittent fever. From the bark a peculiar substance is formed, with which the Russians tan leather. The leaves, in infusion, have been used in rheumatism, gout, and cutaneous diseases. Dropsies have been relieved by enveloping the body in the fresh leaves of the birch, exciting perspiration. The sap is useful in complaints of the kidneys and bladder. The bark is used by the Indians for making canoes. The layers of the bark may be placed in the inside of boots and shoes to prevent the feet becoming wet. The white, smooth bark can be written on like paper.

272. Betula rubra. Red birch. Possesses similar properties.

273. Castanea. Two species; 20, 13, L.

Castanea Americana. Chestnut. The fruit of this valuable tree is well known. Chestnuts are too flatulent to be very healthy. The wood is valuable and durable for fences. The bark is a powerful astringent, and is used as such in tanning, and in medicine. The inner bark, boiled in milk and water, has been used successfully as an astringent in dysentery and diarrhoeas, which require to be restrained after the use of physic.

274. Comptonia. 20, 13, L.

Comptonia asplenifolia. Sweet fern. Sec. The whole plant has a sweet, sickish, spicy odour, which manifests itself by rubbing. It is astringent and tonic, and is used in common practice in diarrhoea, and similar affections. It contains benzoic acid and resin. According to Schœpf, chewing the roots stops bleeding at the lungs. It may be used as a substitute for the more expensive balsams, in asthma, bronchitis, \&c. A decoction of the plant is used here as an internal remedy, and as a wash in cases of poisoning with sumach and other external irritants. 
275. Corylus. Five species; 20, 13, L.

Corylus Americana. Common hazel. The fruit is said to be good in inflammation of the kidneys. The oil is supposed to be anodyne, and good for the toothache.

\section{Fagus. Three species; 20, 13, L.}

Fagus ferruginia. Beech. This is a most valuable wood, and is much used in the arts. A decoction of the leaves is useful in burns and scalds, and for frost-bitten limbs. The bark, simmered with oil or butter, is useful for the same purposes. The nuts yield a good deal of bland oil, and they are pleasant to eat. Western Massachusetts abounds in beech.

277. Quercus. Eighty-four species; 20, 13, L.

Quercus alba. White oak. Off.

278. Quercus prinos discolor. Swamp white oak.

279. Quercus tinctoria. Black oak. Off.

280. Quercus prinos acuminata. Yellow oak, and other species. All the oaks are valuable timber trees, and the bark from them is extensively used as an astringent and corroborant.

281. Salix. One hundred and fifteen species; 20, 2, L.

Salix ligustrina. Champlain willow. Off.

282. Salix vitellina. Yellow willow.

283. Salix Viminalis. Osier; basket willow, and other species. The bark of the willow has been employed as a substitute for Peruvian bark in intermittent fevers. The bark yields salicin, a substance similar to quinine, and employed in the same manner, and for the same purposes. The dose of the salicin is from two to eight grains. The decoction of the willow has been employed in foul and indolent ulcers.

284. Populus. Eight species; 21, L.

Populus tremuloides. Poplar; American poplar. Sec. This is the celebrated tonic bitter of the Thompsonians, or steamers. The bark is somewhat astringent, and has been used in tanning. The 
buds are balsamic, sudorific, stimulant, and tonic. They form a good ointment for the cure of gout, rheumatism, burns, and diseases of the skin. Internally, they are diuretic, and are used in asthma. The bark yields populine.

285. Populus balsamifera. Balsam poplar. This plant is similar in its properties to the balsam of copaiba, but, perhaps, more stimulating. Its properties reside in the buds of the leaves, which contain a great deal of balsam, which yields best to spirit. This spirituous balsam is a valuable vulnerary, and is a useful stimulant pectoral.

\section{N. O.-Terebinthines.}

286. Juglans. Eleven species; 20, 13, L.

Juglans cathartica. Butternut. Off. The cathartic properties of this useful tree are too well known to need description here. The fruit is the pleasantest of any of the nuts.

287. Juglans squamosa. Shellbark hickory, and the

288. Juglans porcina, pignut hickory, possess somewhat similar properties, though in less degree. An infusion of the leaves in water, and washing a horse with them in fly-time, prevents the annoyance of those insects.

N. O.-Conifera. 20, 16, L.

289. Larix Americana. Larch; hackmatack; tamarick. This is a beautiful tree, resembling the pines; but the leaves are deciduous in the fall. Its properties are a fine balsam, similar to turpentine; and it is good for wounds, bruises, \&c.

290. Abies. Synonym, Pinus.

Abies Canadensis. Hemlock spruce. Off. The bark is astringent, and it is used in tanning. A very fine powder of it, sprinkled over excoriated nipples, and other excoriations, is very soothing, and often heals them when other applications fail. The balsam of the hemlock is used in medicine, but it is not collected in great quantities. The essential oil is stimulating, and is much used by the common people in cases of rheumatism, sprains, \&c. Fomentations with the leaves and branches relieve local pains and bruises. 
291. Abies balsamifera. Balsam of fir; silver fir. Off. This balsam exudes from the bark of the tree, and it is sometimes obtained by boiling, but it is not of so good a quality. It is rather thicker than molasses, and of a light straw colour. It becomes thicker by standing. By distillation, it affords an essential oil. The balsam is soluble in alcohol. It is diuretic, and is used for the same purposes as the balsam copaiba, and is a very good substitute for it. The dose is from thirty to sixty drops on sugar.

292. Abies alba. Single spruce.

293. Abies nigra. Black, or double spruce. From the essence of spruce procured from these trees, and from the leaves of them are made spruce beer, so universally admired. The bark is astringent and sudorific. The resin procured from these trees nearly resembles frankincense. Josselyn, according to Rafinesque, says it is good in powder to reproduce flesh. It is used by quacks in powder, and in infusion, for complaints of the stomach and bowels, gravel, and rheumatism.

294. Pinus, including abies. Thirty-seven species.

Pinus mitæ. Yellow pine. Off.

295. Pinus rigida. Pitch pine. Off.

296. Pinus strobus. White pine. All the pines produce the turpentine of commerce, the properties of which are well known. The bark of the Pinus strobus is used by the Indians in poultice for the piles, and for ulcerations. They make a drawing plaster by boiling the roots. They use the decoction of the buds as a purgative, and the cones or strobiles in rheumatism. They use the tar of it dissolved in spirit as a wash in burns, tetter, and the itch. Raf. The bark is used with spikenard formed into syrup in coughs, and in resin for fresh wounds.

\section{N. O.-NAIDES.}

297. Lemna. Six species; 20, 2, L.

Lemna minor. Duck's meat. This singular plant, which floats on the top of stagnant water, is called duck's meat, because ducks are peculiarly fond of it. Ray considered an infusion of it a secret against the jaundice, when six ounces of it are taken in white wine

voL. II. -59 
for nine mornings in succession, fasting. $A^{\prime}$ cataplasm of it has been used against the gout, and to alleviate the pain of the piles.

$$
\text { N. 0.-Urtices. }
$$

298. Morus. Ten species; $20,4, \mathrm{~L}$.

Morus rubra. Red mulberry. The fruit is refrigerant. It is used in the form of syrup, and in its raw state, and in confection; good in sore throat, angina, nervous fever, \&c. The bark is said to expel the tapeworm. The fruit contains the tartaric acid.

$$
\text { N. O.-Junci. }
$$

299. Sagittaria. Ten species; 20, 13, L.

Sagittaria sagittifolia. Arrow-head. This, made into bread and soups, is esculent in China. It is slightly astringent; it is discutient, and checks the flow of milk when applied to the breasts of nursing women. It is of use when applied to œdematous limbs.

\section{N. O.-CONIFERE.}

300. Thuja. Six species; 20, 16, L.

Thuja occidentalis. Arbor vitæ; white cedar. Sec. This beautiful tree is indigenous in Massachusetts, as well as cultivated. The leaves are used in medicine, and from them an essential oil is distilled, which is highly stimulant and aromatic, and has been employed in chronic rheumatism; when used with care, it is vermifuge and diuretic.

\section{N. 0.-JASMINEE.}

301. Fraxinus. Sixteen species; 21, 2, L.

Fraxinus acuminata. White ash. Ash trees are very valuable for timber; such as

302. Fraxinus tomentosa. Red ash.

303. Fraxinus sambucifolia. Black ash. The bark of these is bitter and astringent, and is useful for hemorrhages. The leaves, infused in a poultice, are considered useful in the bites of snakes. It is said the leaves are very poisonous to the rattlesnake, and that these reptiles will sooner run through a fire than over these leaves. The seeds are aromatic, and diuretic. 


\section{N. O.-CONIFER E.}

304. Juniperus. Fourteen species; 21, 16, L.

Juniperus Virginianum. Red cedar. Off.

305. Juniperus sabina. Savine. Off. This and the above are similar in their properties; they are stimulant, emmenagogue, and diaphoretic. The leaves are often resorted to by dissolute females for the purpose of procuring abortion; but they are feeble agents, and are sometimes attended with danger. The principal uses to which they are now applied are the formation of the savine cerate, which is used for keeping up discharges from blistered surfaces. The oil of cedar is considerably used in rheumatic affections; the timber is the most durable in the world, and admits of a high polish.

306. Juniperus communis. Juniper. Off. The berries of this species are one of the most useful diuretics.

307. Taxus. Ten species; 21, 16, L.

Taxus Canadensis. Yew tree; China wood. The leaves of this shrub are said to be poisonous to cattle and sheep. The berries contain sugar, a red fat, malic acid, gum, \&c., and an oil which is used in China for lamps.

308. Gerardia quercifolia. N. O. Oak-leaved gerardia. Rafinesque says this is the specific of the Sioux Indians for the bite of the rattlesnake; and, likewise, for the toothache.

\section{Cryptogamia.}

309. Adiantum pedatum. Maiden hair; rock fern. The plant is slightly aromatic and astringent. Its active properties reside in a mucilage with this astringent. Its principal use is as a pectoral and expectorant. In the form of syrup, I have often used it with success in chronic coughs.

310. Aspidium. Twenty-five species in America.

Aspidium filix mas. Male fern. Sec. This is the celebrated vermifuge, destroying tapeworms, of Madam Nouffer, for which she was liberally rewarded by her native government of Switzerland. It does not answer the high encomiums bestowed upon it. The plant has been used for rickets. 
311. Asplenium. Many species.

Asplenium ruta mararia. Spleenwort. It grows in low woods near moist meadors, and among rocks. The decoction of the leaves is pectoral, diuretic, and mildly astringent. They open obstructions of the viscera, and promote expectoration, allay pain in the urinary organs, by gently carrying off the sand and gravel, and they have been said to have cured the venereal disease used in decoction.

312. Equisetum arvensi. Cat-tail; horse-tail. This is a most troublesome weed in our meadows and pastures. Cattle will not touch it unless severely pressed with hunger, in which case it brings on a severe relax and dysentery. Horses eat it with impunity; but it is noxious to sheep. It is astringent and diuretic. It is sometimes used in bleeding at the stomach, in gonorrhœa, and in phthisis. This, and several other species are in considerable use in tanning and dressing leather.

313. Equisetum hymale. Scouring rush. This plant is much used in scouring wood, metals, \&c.; said to be good for cattle in winter. It is used, in Italy, for cattle as a diuretic, and is good for cattle discharging blood. I have often given an infusion of it in cases of strangury.

314. Fungi. Mushrooms. One hundred and fifty species; most of them found here. Two species are tonic and bitter, the helvella amara and boletus laricis. All those which afford milk, and are deliquescent, and of a fetid odour, are poisonous, being narcotic and acrid in their properties. The remedies for eating these species are a speedy emetic, purgatives, emollient and acid drinks.

315. Lycopodium complanatum. Sec. Ground pine; dead man's hand. This is used by Stewart for the cure of colic. It is diuretic, emetic, emmenagogue, nervine, \&c. It is employed in diarrhœe, dropsy, gout, and scurvy. Externally, it is used for the cure of ulcers, tinea capitis, and hepatic eruptions. The decoction kills lice, and is used to improve bad wine. The pollen is used in fireworks.

316. Polypodium vulgare. Polypod. The root, which is the part used, is sweet and mucilaginous to the taste. It is vermifuge and demulcent, cathartic, and pectoral. The syrup is used in coughs, and in the rickets and lumbago. In strong decoction, it is thought 
to be cathartic and vermifuge. The ancients employed it in bilious affections, in coughs and catarrhs, and in maniacal and melancholic cases.

317. Osmunda regalis. Royal osmund; buckthorn brake. Lindley says the rhizoma is tonic and styptic, and said to be serviceable in cases of rachitis. The centre bulb, or nucleus, just above the roots, is highly mucilaginous and corroborant. Infused in spirit, until it becomes ropy, it is much in vogue for the cure of rheumatism, weakness of the back, swellings, and indolent tumours, by bathing the parts affected with it. It is also much in use in female weaknesses, and in all cases of general debility.

\section{N. O.-Mrricace}

318. Myrica cerifera. Bayberry. Off. The wax made from the berries of this plant has been successfully used by Fahnestock, of Lancaster, Pa., in cases of dysentery. I have not been successful in the use of it in this affection. The root is stimulant and acrid, antispasmodic and astringent. Dr. Bigelow says the bark of the root is acrid and astringent; in large doses, producing vomiting accompanied by a burning sensation; constipation usually follows. The powder is very stimulating and acrid. The fruit is enveloped with an aromatic waxy secretion, which may be collected and purified, and used like beeswax and tallow. This is called bay-wax, and bayberry tallow. It is used in pharmacy for ointments for various purposes, and it is mild or stimulant as it is more or less pure. Next to the divine lobelia, the steamers make use of the bark of the root in cases of debility.

319. JeSTIS-WEED. I cannot close this notice of our medicinal plants, without inviting the attention of my professional brethren throughout the Union towards this plant, which is said to be so sovereign in the cure of the bite of the deadly rattlesnake. I have in vain endeavoured to ascertain the botanical name of the plant, by inquiry of my classes, in the various medical colleges in which I have lectured, who have resided in different sections of the United States, and have instituted inquiries in our medical journals in relation to its scientific name and history; I have not succeeded in finding it. This shows how arbitrary are our English or common names for plants. I hope, through the medium of this communication, some one of our brethren may be able to inform the public what it is. 
The late horrible death of one of our professional brethren in the city of New York, from the bite of a rattlesnake, should excite a diligent inquiry into a remedy for this fatal poison. The late Dr. B. S. Barton, of Philadelphia, in his Med. and Phys. Journal for 1808 , gives a long paper upon the successful use of this plant in the cure of the bite of the rattlesnake, in nine cases, by a Mr. Haynesworth, probably of one of the southern or south-western States. Where he is from, and what is the botanical name of the plant, I cannot learn. I hope some of my readers will be more successful, and communicate the result of their inquiries.

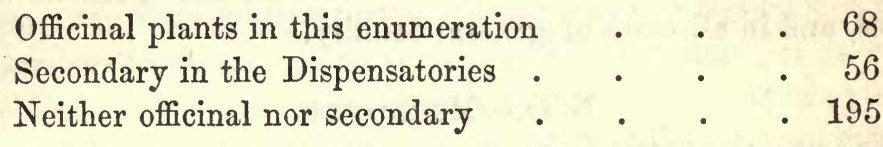

The following is the number of plants in the orders enumerated:-

$\begin{array}{lrlr}\text { Araliaceæ } & 4 & \text { Urticaceæ } & 4 \\ \text { Umbelliferæ } & 13 & \text { Euphorbiaceæ } & 2 \\ \text { Ranunculaceæ } & 14 & \text { Geraniaceæ } & 4 \\ \text { Papaveraceæ } & 2 & \text { Balsamineæ } & 1 \\ \text { Nymphiaceæ } & 2 & \text { Polygalaceæ } & 1 \\ \text { Podophylleæ } & 1 & \text { Violaceæ } & 6 \\ \text { Cruciferæ } & 10 & \text { Droseraceæ } & 1 \\ \text { Fumariaceæ } & 1 & \text { Caryophyllaceæ } & 4 \\ \text { Capparideæ } & 1 & \text { Crassulaceæ } & 1 \\ \text { Berberideæ } & 2 & \text { Chenopodiaceæ } & 2 \\ \text { Magnoliaceæ } & 2 & \text { Phytolacaceæ } & 1 \\ \text { Laurineæ } & 2 & \text { Polygonaceæ } & 3 \\ \text { Malvaceæ } & 6 & \text { Pyrolaceæ } & 3 \\ \text { Tiliaceæ } & 1 & \text { Lobeliaceæ } & 2 \\ \text { Hypericeaneæ } & 2 & \text { Plantageneæ } & 2 \\ \text { Saxifrageæ } & 3 & \text { Compositæ } & 30 \\ \text { Hamameliaceæ } & 1 & \text { Stellatæ } & 5 \\ \text { Circoraceæ } & 1 & \text { Apocynaceæ } & 2 \\ \text { Salicariæ } & 1 & \text { Gentianaceæ } & 3 \\ \text { Aristolochiæ } & 1 & \text { Convolvulaceæ } & 2 \\ \text { Rosaceæ } & 17 & \text { Orobancheæ } & 6 \\ \text { Leguminosæ } & 6 & \text { Solanaceæ } & 25 \\ & & & \end{array}$


Verbenaceæ

Boraginaceæ

Alismaceæ

Iridaceæ

Orchideæ

Melanthaceæ

Smilaceæ

Liliaceæ

Typhiaceæ

Aroider

Cinchonaceæ

Caprifoliaceæ

Anacardiaceæ

Xanthoxylacer

Celastraceæ

Rhamnaceæ
20

2

1

1

5

3

6

2

1

5

6

3

4

1

1

6

Amentaceæ

17

Ulmacer

1

Narcissus

1

Acera

2

Thymelaceæ 1

Ericaceæ 7

Fabaceæ 2

Portulaceæ 1

Cistaceæ 1

Scrophulariaceæ 1

Amaranthaceæ 1

Terebinthineæ 3

Coniferæ

12

Naides

1

Cryptogamia 


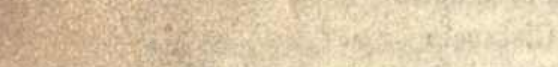

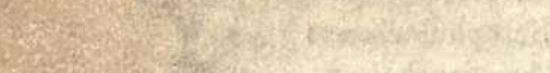
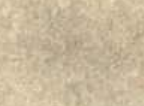

This
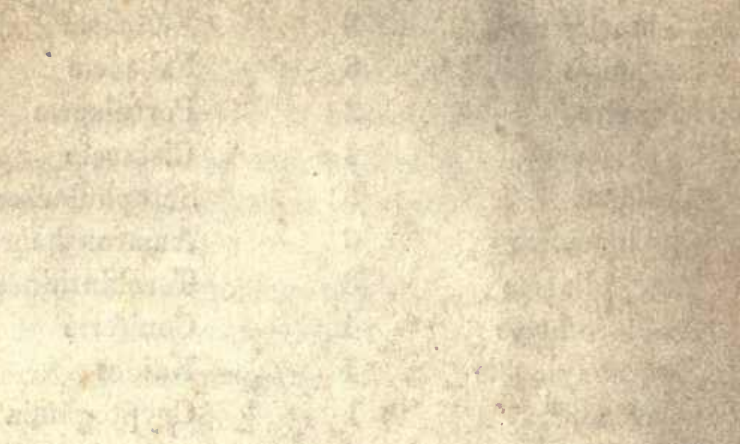

कin: (2) 
RETURN TO the circulation desk of any

University of California Library

or to the

NORTHERN REGIONAL LIBRARY FACILITY

Bldg. 400, Richmond Field Station

University of California

Richmond, CA 94804-4698

ALL BOOKS MAY BE RECALLED AFTER 7 DAYS

2-month loans may be renewed by calling

(415) 642-6233

1-year loans may be recharged by bringing books to NRLF

Renewals and recharges may be made 4 days prior to due date

\section{DUE AS STAMPED BELOW}

\section{NRLF LIBKARY USE UNI 2490}


